\title{
Mapping diagenesis in archaeological human bones
}

\author{
Kaare Lund Rasmussen ${ }^{1 *}$ (D) George Milner ${ }^{2}$, Lilian Skytte ${ }^{1}$, Niels Lynnerup ${ }^{3}$, Jørgen Lange Thomsen ${ }^{4}$ \\ and Jesper Lier Boldsen ${ }^{5}$
}

\begin{abstract}
We describe a procedure for ascertaining the extent of diagenesis in archaeological human skeletons through the distribution of $\mathrm{Sr}, \mathrm{Ba}, \mathrm{Cu}, \mathrm{Pb}, \mathrm{Fe}$, and $\mathrm{Mn}$ in cross-sections of femoral cortical bone. Element mapping is performed through Laser Ablation Inductively Coupled Plasma Mass Spectrometry (LA-ICP-MS). Absolute calibrations of element concentrations were obtained using Inductively Coupled Plasma Mass Spectrometry (ICP-MS) on adjacent dissolved bulk bone samples. By comparing a modern individual to five medieval to early modern Danish skeletons, we demonstrate the degree to which concentrations of trace elements are attributable to diagenesis. Invasion from the exterior bone surface into a degraded part of the outer cortical bone is the most frequently occurring diagenetic change. In the archaeological skeletons investigated, diagenetic modification is restricted to, at most, the outer ca. $0.5 \mathrm{~mm}$ of bone. In one femur, Haversian channels were filled with diagenetic material, which appears to have entered the bone through a network of cavities largely made up by Haversian and Volkmann's canals.
\end{abstract}

Keywords: Human bones, Trace element chemistry, Diagenesis, Bones, Medieval, Denmark

\section{Introduction}

It has long been recognized that the elemental and isotopic composition of human bones are influenced by diet, hence where people resided, so they hold great potential for archaeological and forensic investigations. It is also true that chemical signals from bones can be affected, or obscured altogether, by postmortem alterations following burial [1-3]. Much remains to be learned about those processes, collectively referred to as diagenesis. Nevertheless, for the organic fraction of bone, it is well known that bacterial activity affects collagen, which is of special relevance for radiocarbon dating [1,3,4]. Diagenesis can also alter hydroxyapatite, mainly through groundwater contact with bone surfaces or within the bone via canaliculi, Haversian and Volkmann's canals, or postmortem cracks. There is also evidence that micro-bacterial attack can alter the inorganic structure of bones [1].

\footnotetext{
*Correspondence: klr@sdu.dk

${ }^{1}$ Cultural Heritage and Archaeometric Research Team (CHART), Department of Physics, Chemistry and Pharmacy, University of Southern Denmark, Campusvej 55, 5230 Odense M, Denmark

Full list of author information is available at the end of the article
}

With regard to the concentration of elements in the inorganic fraction of bone, notably $\mathrm{Sr}$ and $\mathrm{Ba}$, initial enthusiasm in the 1960 s over their potential to provide useful information about past people's lives was soon dampened, but not extinguished, by concerns over diagenesis and geographical variability in element availability [5-17]. Such concerns resulted in archaeological attention largely switching to stable isotopes in the 1990s, notably to $\mathrm{C}, \mathrm{N}$, and $\mathrm{Sr}$, for estimating dietary composition and identifying migrants [18-25]. Although interpretations of the isotopic composition of long-buried bones are not without their problems, the study of stable isotopes has developed into a growing, indeed essential, component of archaeological research.

Despite the focus on stable isotopes, element concentrations have continued to be used to assess diet and mobility in the past [26-31]. An argument has been made that elemental data, especially for $\mathrm{Sr}$ and $\mathrm{Ba}$, show significant variation that cannot be attributed to diagenesis alone. Contrary to early studies, the state of bone apatite preservation is now carefully evaluated, and diagenesis control samples are measured [27, 29]. Similarly, $\mathrm{Pb}$ and $\mathrm{Hg}$ concentrations in bone, which are 
sometimes astonishingly high, have been interpreted as resulting from exposure attributed to residential and occupational settings, everyday objects, and medical treatments [28, 29, 32-35]. For $\mathrm{Pb}$ and $\mathrm{Hg}$, it appears that hydroxyapatite is robust against diagenesis, at least for European bones dating as far back as the Middle Ages.

By investigating the effect of diagenesis, we return to the evaluation of the potential of the elemental composition of archaeological bones for providing perspectives on the lives of past people. Because the original biogenic signal is of interest, the postmortem alteration of bone must be insignificant. To ensure reliable results, a better understanding of the elemental distribution in bone at a microstructural level is needed, as is a means of eliminating specimens where the biogenic signal is obscured through the effects of burial.

In the present study, Danish medieval to early modern femora, as well as one from a modern individual, were examined. Bulk bone samples were analyzed by Inductively Coupled Plasma Mass Spectrometry (ICP-MS), and bone microstructure was characterized by Laser Ablation ICP-MS (LA-ICP-MS). Concentrations of ten elements- $\mathrm{Ca}, \mathrm{Na}, \mathrm{Mg}, \mathrm{Zn}, \mathrm{Sr}, \mathrm{Ba}, \mathrm{Cu}, \mathrm{Pb}, \mathrm{Fe}$, and $\mathrm{Mn}-$ were estimated in bulk samples through ICP-MS. The distributions of several of these elements- $\mathrm{Sr}, \mathrm{Ba}, \mathrm{Cu}, \mathrm{Pb}$, $\mathrm{Fe}$, and $\mathrm{Mn}-$ to the level of individual osteons (Haversian systems) in bone cross-sections were characterized using LA-ICP-MS.

Of particular interest are the distributions of elements within cortical bone because they can help establish the extent of diagenetic change. That requires high-resolution analyses of bone microstructure. The chemical composition of cross-sections of long-buried bones has previously been examined with scanning electron microscopy energy dispersive X-ray (SEM-EDX), X-ray fluorescence (XRF), proton induced X-ray emission (PIXE), synchrotron radiation (SR), and atomic absorption spectroscopy (AAS) [36-41]. The instrumentation used in the present study yields images with high resolution and good detection limits, hence a good approximation of precisely where specific elements are concentrated. In that respect, the results of this study are much like those achieved in a previous examination of paleontological specimens [42]. Investigations of old bones complement analyses of modern specimens where some elements have been shown to be unevenly distributed in compact bone [43].

In the archaeological material, it is reasonable to expect variation in the concentrations of elements across bone cross-sections to be attributable to both biogenic and diagenetic processes. Using the elemental maps of bone cross-sections, the Danish specimens were examined for microstructural features associated with osteons.
If observable, one can have increased confidence in the retention of a biogenic signal.

Distributions of elements seen in cross-sections consistent with those in modern (i.e. not buried) bones are a means of identifying archaeological specimens that retain a biogenic signal. The cross-sections also provide a way to investigate how elements and foreign particles enter cortical bone after burial. Investigating the processes through which the bone composition is altered over time and the extent to which diagenesis affects the original biogenic signal are essential if skeletal remains are to be used to provide valid information about past people's lives. Once reliable results are obtained, especially through analyses of large numbers of bulk bone samples, it is likely that several elements, either singly or in combination, can be used to characterize the life experiences of past people.

Recommendations are made to ensure that traditional, and far less expensive, bulk analyses of cortical bone yield reliable results. High-resolution LA-ICP-MS images show the extent to which mechanical surface decontamination will remove diagenetically altered material from archaeological bones, at least those from contexts similar to the several sampled Danish sites.

\section{Biogenic and diagenetic signals}

It is reasonable to start with the assumption that after burial the inorganic fraction of bone undergoes changes over time. That can come about through elements in solution or suspension entering openings in dense cortical bone, such as osteon lacunae [44]; tunnels produced by fungi, bacteria, and plant roots [44-50]; and cracks as small as microscopic fissures $[46,51,52]$. It can also occur through recrystallization, ion substitution, ion diffusion, or adsorption in the inorganic fraction of the bone $[18,49,53]$. To be useful, a bone's chemical signature at the time of death must be distinguished from postmortem alterations that resulted from exposure to soil and groundwater. The former can be instructive about the life experiences of past people, providing perspectives that are unavailable from other sources of information. The latter yield little of value to the study of past life histories. Yet they can still serve a useful purpose, such as when distinguishing among burial environments as shown by As concentrations in Mesolithic bones [54].

Of the elements in this study, Fe and Mn have consistently been attributed to diagenetic processes $[6-8,28-31$, $38,39,55-58]$. This finding comes as no surprise given the ubiquity of these elements in soil and groundwater. Another element clearly affected by diagenesis is aluminum (Al). It mainly originates from clay minerals, and its concentration in bone will be altered through adhesion or when tiny soil particles enter the bone though 
postmortem cracks or Haversian and Volkmann's canals $[6-8,28-31,39,58]$.

Past studies have not always yielded similar results, as illustrated by $\mathrm{Cu}$ that was said to be unaffected $[7,55]$ or affected by diagenesis [40]. The same is true of $\mathrm{Mg}$, where it was sometimes $[7,8]$, but not always [55], reported as being useful in archaeological studies.

Other elements used to characterize past life histories include $\mathrm{Sr}[6-8,30,39,59,60]$ and $\mathrm{Ba}[5,6,30,59]$. Both are divalent cations, which can substitute for $\mathrm{Ca}$ in hydroxyapatite. But even for these two elements, cautions have been raised over their interpretation because of diagenetic effects: $\mathrm{Sr}[53,61]$ and $\mathrm{Ba}[6,40,53,61]$. Other elements reported as not being affected by postmortem changes in the inorganic fraction of bone include $\mathrm{Ca}[7$, 29, 31], Zn [7, 8, 39, 55], and $\mathrm{Pb}[29,34,39]$.

In archaeological and paleontological specimens, there is often a concentration gradient from the cortical bone surface to the interior. A decline to consistently lower concentrations is steep for some elements, as indicated by plots of element concentrations or cross-section images of the spatial distribution of elements. They include several of interest to this study: Fe [39, 50, 62, 63], Zn [50, 62-64], Sr [36, 62, 63], Cu [36, 50, 63], Mn [62], and $\mathrm{Ba}[62]$.

Pretreatment is essential to obtain bulk sample results that might approximate the composition of living bone. It includes taking samples from the interior of compact bone to eliminate surface contamination $[12,29,30,34$, 58]. Here the outer $1-2 \mathrm{~mm}$ of the exterior part of the bone is mechanically removed, and what remains is analyzed.

An alternative approach is to use a weak acid to dissolve mineral phases attributable to diagenetic recrystallisation, while leaving what is thought to be biogenic hydroxyapatite for analysis [12, 58, 65-67]. Its efficacy in returning reliable $\mathrm{Sr}$ values in archaeological and paleontological bones consistent with their original state, however, has been questioned $[68,69]$. The nature of visible bone microstructure, used as a measure of preservation, has also been found to be related to the original composition of archaeological bone, including its elemental and protein content $[61,70]$.

\section{Materials and methods}

\section{Skeletal remains}

Femora from one modern and five medieval to early modern people, all from Denmark, were analyzed (Table 1). The recent individual was a 29-year-old female who died several decades ago (D35, KLR-10977). This bone sample was obtained for forensic reasons shortly after death, and it was untouched by soil. Archaeological skeletons were selected from 88 individuals that were part of a larger study. The specimens were chosen to capture the variation in diagenetic changes detected by inspecting $\mathrm{Sr}$ distributions in cross-sections of cortical bone. The cross-sections ranged from those where bone microstructure appeared to be intact-that is, complete and fragmentary osteons (Haversian systems) and, perhaps, lamellar bone were visible-to others that showed signs of considerable postmortem alteration. The intent was to cover the range of postmortem change present in archaeological specimens, at least as it is represented by medieval bones from several cemeteries in two parts of Denmark. Sampling the range of variation in bone preservation is an important step in assessing the extent to which long-buried bone retains a biogenic signal. All archaeological skeletons were carefully excavated and contextually well characterized. Estimates of age and sex were experience-based assessments. Such estimates have been shown to be highly accurate in blind tests using modern skeletons of known age and sex [71, 72].

Three of the archaeological skeletons were from excavations in the Lindegaarden cemetery next to the cathedral in Ribe, which is in southwestern Denmark [73]. One female was about 38-48 years old when she died somewhere between AD 1050 and 1536 (K1147, ASR2391, KLR-10516). Another woman around 37-47 years old

Table 1 Individuals selected for this study

\begin{tabular}{llllllll}
\hline Field designation & $\begin{array}{l}\text { Lab designation } \\
\text { (KLR-) }\end{array}$ & $\begin{array}{l}\text { Excavation } \\
\text { designation }\end{array}$ & Source (site) & Date (AD) & Age (years) & $\begin{array}{c}\text { Sex } \\
\text { Observable } \\
\text { disease }\end{array}$ \\
\hline D35 & 10977 & - & Forensic & Modern & 29 & F & None \\
AG134 & 10236 & Kloster II & Svendborg & $1480-1650$ & $38-48$ & F & None \\
A85 & 8348 & SOM 00.390 & Svendborg & $1215-1270$ & $35-70$ & M & None \\
K1147 & 10516 & ASR2391 & Ribe & $1050-1536$ & $38-48$ & F & None \\
K1029 & 10831 & ASR13 & Ribe & $1425-1738$ & $37-47$ & F & Syphilis \\
K1256 & 10810 & ASR13II & Ribe & $1425-1738$ & $45-55$ & M & None \\
\hline
\end{tabular}

Date intervals are inferred from archaeological evidence, except for A85 that is radiocarbon dated and AG134 where the interval is from archaeological evidence combined with radiocarbon dates of samples in related strata 
was interred in the Lindegaarden procession walk where it reportedly cost 4 daler to be buried (K1029, ASR13, KLR-10831, [29]). Her skeleton was found in the second youngest layer of the procession walk, dated stratigraphically to ca. AD 1650-1700. The third individual from Ribe, a male about $45-55$ years old, was put in the ground without a coffin in the courtyard of the procession walk where it cost only 2 daler for a grave (K1256, ASR13II, KLR-10810, [29]). His death is stratigraphically dated to the 1500s. The soil in all of these excavations was rich in clay, wet, and highly anoxic.

Two skeletons came from Svendborg on the southern coast of Funen. A man likely to have been in his early 50 s was from the Sct. Nicolai parish church cemetery (A85, SOM 00.390, KLR-8348). His grave, a trapezoid brickwalled type, is typical of a burial in the 1100s or 1200s, the soil was clay rich and dry, and he has been radiocarbon dated to $898 \pm 28 \mathrm{BP}, \delta^{13} \mathrm{C}=-18.0$ VPDB (K-6530). The $\delta^{13} \mathrm{C}$ corresponds to a marine reservoir effect of 82 years, yielding a calibrated age of AD 1215-1270 $( \pm 1$ $\sigma$ interval), consistent with the form of the grave [74]. The second individual from Svendborg was a woman about 38-48 years old who was buried without a coffin in the Franciscan Friary's laymen cemetery (AG134, KLR-10236 $[29,75])$. The soil was clay rich, wet, and quite anoxic. Based on archaeological evidence and other radiocarbon dated material, she probably died between AD 1480 and 1650.

Two samples from each of the six individuals were taken from femoral cortical bone, just distal to the lesser trochanter. The samples were located adjacent to one another. One was a bulk sample, and the other was mounted in resin, polished, and used for mapping the spatial distribution of elements.

Bone samples were removed from femora using a Dremel MultiPro drill mounted with a sawblade. The blade was cleaned in MilliQ water (Merck Millipore, Billerica, MA, USA) and heated in an ethanol flame between each sample. Rinsing is standard procedure in the Cultural Heritage and Archaeometric Research Team (CHART) lab at the University of Southern Denmark, and it is designed to avoid contamination from dust or leftover material from previous use. Blades were heated to eliminate $\mathrm{Hg}$ contamination. Mercury, which was measured separately, is not reported here. Bone-sampling work took place on two sheets of Al-foil. The lower one prevented contamination from the table, and the upper one was replaced after each bone was sampled. The individual who took the samples was equipped with hairnet, dust mask, lab coat, and disposable latex gloves changed between each bone.

Bulk bone samples were taken from the interior of cortical bone after the outer 1 to $2 \mathrm{~mm}$ of bone was ground away using the Dremel drill. Cut sections analyzed by LA-ICP-MS were mounted in Struers' Epoxy resin. These mounted bone samples were subsequently ground with 500 and 1200 mesh $\mathrm{SiC}$, followed by polishing with a $9 \mu \mathrm{m}, 3 \mu \mathrm{m}$ and $1 \mu \mathrm{m}$ diamond paste. Grinding and polishing produced a surface suitable for laser ablation.

\section{Soil samples}

Soil samples near the skeletons in the Ribe cemetery were collected during excavation and frozen until analysis. The 78 soil samples were pre-treated the same as the bone samples. Thus, only bioavailable elements were brought into solution and analyzed, leaving behind geologically bound elements.

\section{Solution ICP-MS}

Calcium, $\mathrm{Na}, \mathrm{Mg}, \mathrm{Zn}, \mathrm{Sr}, \mathrm{Ba}, \mathrm{Cu}, \mathrm{Pb}, \mathrm{Fe}$, and $\mathrm{Mn}$ were analyzed by solution ICP-MS. Samples consisted of ca. $20 \mathrm{mg}$ of bone powder. They were handled by a stainlesssteel spoon rinsed in MilliQ water and heated in an ethanol flame between each sample. After being weighed, the bone powder was transferred to a clean $50 \mathrm{~mL}$ disposable polypropylene filtration tube (SCP Science digiTubes). The sample was dissolved with $2 \mathrm{~mL}$ of concentrated 69\% ICP-MS-grade $\mathrm{HNO}_{3}$ and $1 \mathrm{~mL}$ of concentrated $30 \%$ ICP-MS-grade $\mathrm{H}_{2} \mathrm{O}_{2}$. A lid was loosely fitted on the tube before it was placed on a shaking table for over three hours. The quantity of $\mathrm{H}_{2} \mathrm{O}_{2}$ consumed during the dissolution step depended on the amount of organic compounds, such as collagen, in the sample. The $\mathrm{H}_{2} \mathrm{O}_{2}$ added was in excess of what was needed to destroy all organic compounds. Surplus $\mathrm{H}_{2} \mathrm{O}_{2}$ was removed with $400 \mu \mathrm{L}$ of concentrated $37 \%$ ICP-MS grade $\mathrm{HCl}$. Once it was added, the tube with its loosely fitted lid was placed on a shaking table overnight.

Samples were then diluted to $10 \mathrm{~mL}$ with MilliQ water and filtered through a digiTube ${ }^{\circledR}$ vacuum filtration system. Further dilution was done in $15 \mathrm{~mL}$ disposable polypropylene centrifuge tubes according to the concentrations of the specific sample, usually a $3 \mathrm{~mL}$ sample solution and $9 \mathrm{~mL}$ MilliQ water. Through this process, diluted samples reached an acid concentration of approximately $1 \%$ suitable for ICP-MS analyses.

Solution ICP-MS analyses were performed using a Bruker ICP-MS 820 with a frequency matching RF-generator and a Collision Reaction Interface (CRI) operated with either helium or hydrogen as a skimmer gas. Samples were introduced through a Bruker SPS3 autosampler with an OneFast flow injection inlet system. The radiofrequency power was $1.40 \mathrm{KW}$, plasma gas flow rate was $15.50 \mathrm{~L} \mathrm{~min}^{-1}$, auxiliary gas flow rate was $1.65 \mathrm{~L} \mathrm{~min}^{-1}$, sheath gas flow rate was $0.12 \mathrm{~L} \mathrm{~min}^{-1}$, and the nebulizer gas flow rate was $1.00 \mathrm{~L} \mathrm{~min}^{-1}$. Isotopes measured 
without skimmer gas were Mg24, Al27, Ca44, Mn55, Sr88, Ba137, and Pb208. The CRI reaction system was used for $\mathrm{Fe}, \mathrm{Cu}$, and $\mathrm{Zn}$ because of interferences with polyatomic species resulting from a combination of isotopes from the argon plasma, reagents, and bone matrix. The isotopes Fe56 and Zn66 were measured with hydrogen as skimmer gas, and Cu63 with helium. A mixture of Sc45, Y89, and Tb159 was used as internal standard, and it was added continuously to all samples. The dwell time on each peak was between 5 and 20 ms. Five replicates were made for the dissolved bone samples, each measured with 30 mass scans. The ICP multi-element standard solution XXI for MS from Merck was prepared in $1 \% \mathrm{HNO}_{3}$ at five concentrations $\left(1,10,20,100\right.$ and $\left.200 \mu \mathrm{g} \mathrm{L}^{-1}\right)$. For each element, at least three standards were selected to fit the appropriate sample concentration range. For the main element $\mathrm{Ca}$, three standards (Fluka TraceCert ${ }^{\circledR} \mathrm{ICP}$ Standard) corresponding to concentrations of 10, 20, and $25 \mathrm{wt} \%$ were used. Isotopes with higher than expected concentrations had count rates attenuated automatically by the MS detector. Blank samples of MilliQ water and $1 \% \mathrm{HNO}_{3}$ were run before the standard blank to ensure no contaminants lingered in the system at start up. A $1 \%$ $\mathrm{HNO}_{3}$ blank sample was analyzed between each bone sample to rinse the system and to avoid possible memory effects. Each day an in-house standard sample manufactured from a homogenized medieval bone was analyzed along with the samples to monitor the overall performance of the system. An international modern bone standard, NIST SRM-1486, was also analyzed daily. The limit of quantization (LOQ) based on 6 months of meas-

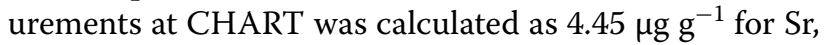
$13.5 \mu \mathrm{g} \mathrm{g}^{-1}$ for $\mathrm{Fe}, 4.88 \mu \mathrm{g} \mathrm{g}^{-1}$ for Ba, $0.85 \mu \mathrm{g} \mathrm{g}^{-1}$ for $\mathrm{Pb}$, $2.97 \mu \mathrm{g} \mathrm{g}^{-1}$ for $\mathrm{Mn}$, and $2.56 \mu \mathrm{g} \mathrm{g}^{-1}$ for $\mathrm{Cu}$.

\section{Laser ablation ICP-MS}

Laser ablation was undertaken on intact bone samples with a CETAC LXS-213 G2 equipped with a NdYAG laser. Laser operations, controlled by CETAC-provided DigiLaz G2 software, operated at a wavelength of $213 \mathrm{~nm}$ with a $10 \mu \mathrm{m}$ circular aperture and a shot frequency of $20 \mathrm{~Hz}$. Images of element spatial distributions-they depict variation in element concentration relative to bone microstructure-were typically composed of 100 horizontal lines. Lines were scanned at a speed of $10 \mu \mathrm{m} \mathrm{s}^{-1}$ and were usually ca. $250 \mathrm{~s}$ long. A $10 \mathrm{~s}$ gas blank preceded each line. Helium flow transferring the sample to the ICP-MS was maintained at $600 \mathrm{~mL} \mathrm{~min}^{-1}$.

The ICP-MS analyses were conducted with a Bruker Aurora M90 equipped with a frequency matching RFgenerator. The radiofrequency power was $1.30 \mathrm{KW}$, plasma argon gas flow rate was $16.5 \mathrm{~L} \mathrm{~min}^{-1}$, auxiliary gas flow rate was $1.65 \mathrm{~L} \mathrm{~min}^{-1}$, and sheath gas flow rate was $0.18 \mathrm{~L} \mathrm{~min}^{-1}$. Skimmer gas was not used. Isotopes measured were Mn55, Fe57, Cu66, Sr88, Ba137, and $\mathrm{Pb} 208$, and no interference corrections were applied. The dwell time on each peak was $10 \mathrm{~ms}$, and the total scan time was ca. $360 \mathrm{~ms}$. For Mn55 the signal was attenuated by a factor of 1000 to avoid occasional detector overflow.

Data generated through the LA-ICP-MS procedure were calibrated into absolute concentrations for each element. That involved taking an average of a large representative part of the scanned area, and normalizing it to the bulk concentration determined by solution ICP-MS on an adjacent sample of ca. $20 \mathrm{mg}$. These areas were generally several square $\mathrm{mm}$ and located well away from bone surfaces and major cracks. Their size and placement allowed the generation of averages from many osteons that were unaffected by exogenous elements that had infiltrated damaged areas.

\section{Diffusion rates}

Diffusion lengths for four elements, $\mathrm{Fe}, \mathrm{Sr}, \mathrm{Ba}$, and $\mathrm{Pb}$, were estimated from element-enriched zones corresponding to diagenetically altered bone visible in LAICP-MS cross-sections of archaeological femora. These are elements for which diffusion rates in cortical bone have been reported previously [76]. In the present study, typical diffusion times were calculated based on the length of visually apparent invasion zones through the following equation:

$$
\mathrm{t}=\mathrm{x}^{2} / 4 \mathrm{D} \exp ((273+20) /(273+8.8))
$$

In Eq. $1, \mathrm{t}$ is the characteristic diffusion time, $\mathrm{x}$ is the diffusion length, $\mathrm{D}$ is the diffusion coefficient [76], and the exponential factor accounts for an average temperature of Danish cemetery soil of $8.8^{\circ} \mathrm{C}$. Denmark is characterized by relatively low soil temperatures (yearly average of ca. $8.8^{\circ} \mathrm{C}$ ), and often, but not always, anoxic conditions in soils dominated by clay minerals. That was true of the burial contexts that yielded the skeletons analyzed here.

\section{Results \\ Bulk samples}

Table 2 lists the ICP-MS bulk sample results. All of them, except two $\mathrm{Cu}$ measurements, are above the LOQ. Element concentration variation among individuals is considerable, except for $\mathrm{Ca}$ which is metabolically strictly controlled. Concentration values of the five archaeological skeletons normalized to those of the modern individual are depicted in Fig. 1. Averages of soil sample values from the Ribe burial area are also provided in Table 2. 
Table 2 Concentrations in $\mu \mathrm{g} \mathrm{g}^{-1}$ and relative standard deviations (RSD in $\%=1 \sigma /$ concentration* 100 ) for femoral cortical bone from modern (D35) and archaeological (Svendborg, A85 and AG134; Ribe K1147, K1029, and K1256) individuals

\begin{tabular}{|c|c|c|c|c|c|c|c|c|c|c|c|c|c|}
\hline & \multirow{2}{*}{\multicolumn{2}{|c|}{$\begin{array}{l}\text { D35 } \\
\text { KLR-10977 }\end{array}$}} & \multirow{2}{*}{\multicolumn{2}{|c|}{$\frac{\text { AG134 }}{\text { KLR-10236 }}$}} & \multirow{2}{*}{\multicolumn{2}{|c|}{$\frac{A 85}{\text { KLR-8348 }}$}} & \multirow{2}{*}{\multicolumn{2}{|c|}{$\frac{\text { K1147 }}{\text { KLR-10516 }}$}} & \multirow{2}{*}{\multicolumn{2}{|c|}{$\frac{\text { K1029 }}{\text { KLR-10831 }}$}} & \multirow{2}{*}{\multicolumn{2}{|c|}{$\frac{\mathrm{K} 1256}{\mathrm{KLR}-10810}$}} & \multirow[t]{2}{*}{ Ribe soil } \\
\hline & & & & & & & & & & & & & \\
\hline & CONC & RSD & CONC & RSD & CONC & RSD & CONC & RSD & CONC & RSD & CONC & RSD & CONC \\
\hline $\mathrm{Ca}, \mathrm{wt} \%$ & 25.9 & 1.87 & 23.5 & 1.94 & 24.5 & 0.91 & 25.0 & 2.02 & 27.2 & 1.59 & 29.5 & 1.67 & 4.34 \\
\hline $\mathrm{Zn}, \mu \mathrm{g} \mathrm{g}{ }^{-1}$ & 101.0 & 2.70 & 103.9 & 1.10 & 109.8 & 3.51 & 384.7 & 2.65 & 537.0 & 4.39 & 116.8 & 2.92 & 81.9 \\
\hline $\mathrm{Na}, \mu \mathrm{g} \mathrm{g}^{-1}$ & 7931 & 1.02 & 4297 & 3.30 & 4051 & 1.27 & 3643 & 4.56 & 4007 & 2.29 & 4176 & 3.83 & 621 \\
\hline$M g, \mu g g^{-1}$ & 3077 & 2.33 & 1224 & 3.20 & 920 & 2.35 & 832 & 3.23 & 986 & 3.26 & 1069 & 2.86 & 618 \\
\hline $\mathrm{Sr}, \mu \mathrm{g} \mathrm{g} \mathrm{g}^{-1}$ & 128 & 0.60 & 395 & 1.09 & 206 & 0.37 & 207 & 0.45 & 265 & 0.28 & 406 & 0.48 & 109 \\
\hline $\mathrm{Ba}, \mu \mathrm{g} \mathrm{g}{ }^{-1}$ & 5.04 & 0.46 & 408 & 1.12 & 188 & 0.28 & 14.2 & 0.92 & 20.4 & 0.66 & 9.55 & 0.90 & 104 \\
\hline $\mathrm{Cu}, \mu \mathrm{g} \mathrm{g}^{-1}$ & $<2.56$ & & $<2.56$ & & 14.6 & 8.05 & 12.1 & 8.39 & 23.0 & 4.79 & 11.3 & 10.9 & 141 \\
\hline $\mathrm{Pb}, \mu \mathrm{g} \mathrm{g}^{-1}$ & 2.87 & 0.65 & 24.9 & 0.95 & 6.21 & 1.26 & 184 & 0.64 & 41.7 & 0.29 & 7.96 & 0.61 & 190 \\
\hline $\mathrm{Fe}, \mu \mathrm{g} \mathrm{g}^{-1}$ & 9.62 & 6.66 & 7959 & 1.42 & 14156 & 2.60 & 463 & 5.53 & 415 & 11.3 & 35.3 & 25.8 & 6300 \\
\hline$M n, \mu g g^{-1}$ & 4.92 & 0.33 & 2686 & 0.94 & 1557 & 0.71 & 178 & 0.15 & 1144 & 0.60 & 6.23 & 0.19 & 400 \\
\hline
\end{tabular}

Two samples have Cu concentrations below LOQ, as established through more than 6 months of measurements using in-house medieval and NIST SRM-1486 bone standards. The last column provides average concentrations for 78 soil samples from the Ribe cemetery treated identically to the bone samples

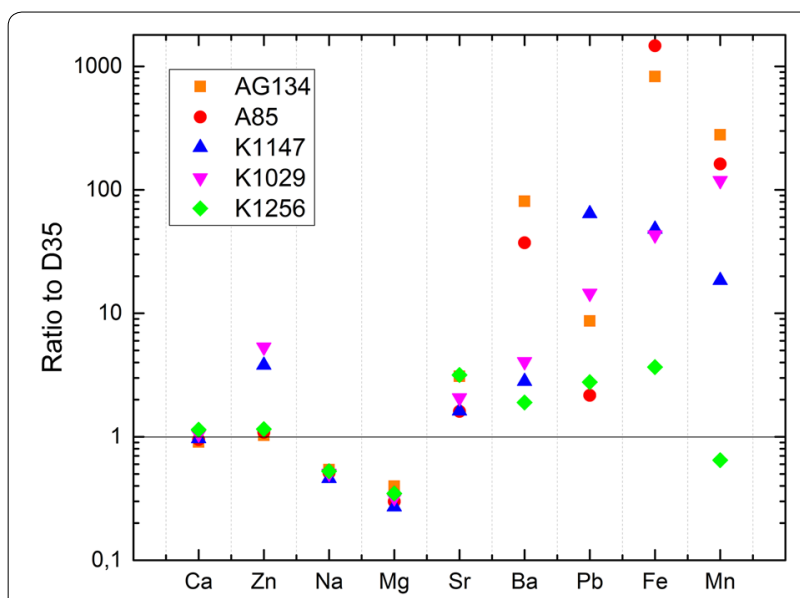

Fig. 1 Bulk analysis results from ca. $20 \mathrm{mg}$ of decontaminated femoral cortical bone, with archaeological samples displayed relative to the modern specimen, D35. Not shown are the Cu results because that element was below LOQ in the modern individual

\section{Archaeological and modern bulk samples}

The first step in investigating the extent of diagenesis involved comparing bulk sample concentrations in the archaeological and modern femora (i.e., buried versus not-buried bones). In Fig. 1, all archaeological bone ICPMS data have been normalized to the modern individual's concentration values. Differences between the modern and archaeological samples can, of course, originate from either dietary intake or diagenesis. The former could be large, given differences in ways of life. There is no absolute threshold beyond which diagenesis can be said to have definitely occurred, but a large deviation from the modern individual serves as a warning that diagenetic processes could have altered the bone to the point where little, if any, information about the person's life can be extracted.

Despite uncertainties in the interpretation of bulk samples, it is prudent to believe that diagenesis quite likely affected $\mathrm{Fe}$ and $\mathrm{Mn}$ concentrations in most individuals. Similarly, Ba in AG134 and A85 from Svendborg and Pb in K1147 and K1029 from Ribe might have a diagenetic origin-at least as inferred from the bulk chemistry data. For deviations from the modern individual that are, relatively speaking, rather small it is impossible to ascertain from these data if diagenesis has occurred. For example, one individual from Ribe, K1256, seems to have been free of a diagenetic effect for all analyzed elements. Variation among individuals in elements that do not deviate far from the modern individual could easily be attributable, in whole or in part, to differences in diet. Given this interpretive ambiguity, bulk samples can only be regarded as a crude guide for detecting diagenesis.

\section{Bone cross sections}

Bulk sample concentrations in Table 2 were used to calibrate LA-ICP-MS data for each element separately by converting count rates into concentrations. Element concentration maps are shown in Figs. 2, 3, 4, 5, 6 and 7 where the modern individual is in the upper left (designated "a" in the figures). Higher concentrations are shown as being lighter than lower concentrations. Exterior bone surfaces are at the top of the figures, and interior trabecular bone is sometimes visible at the bottom. 

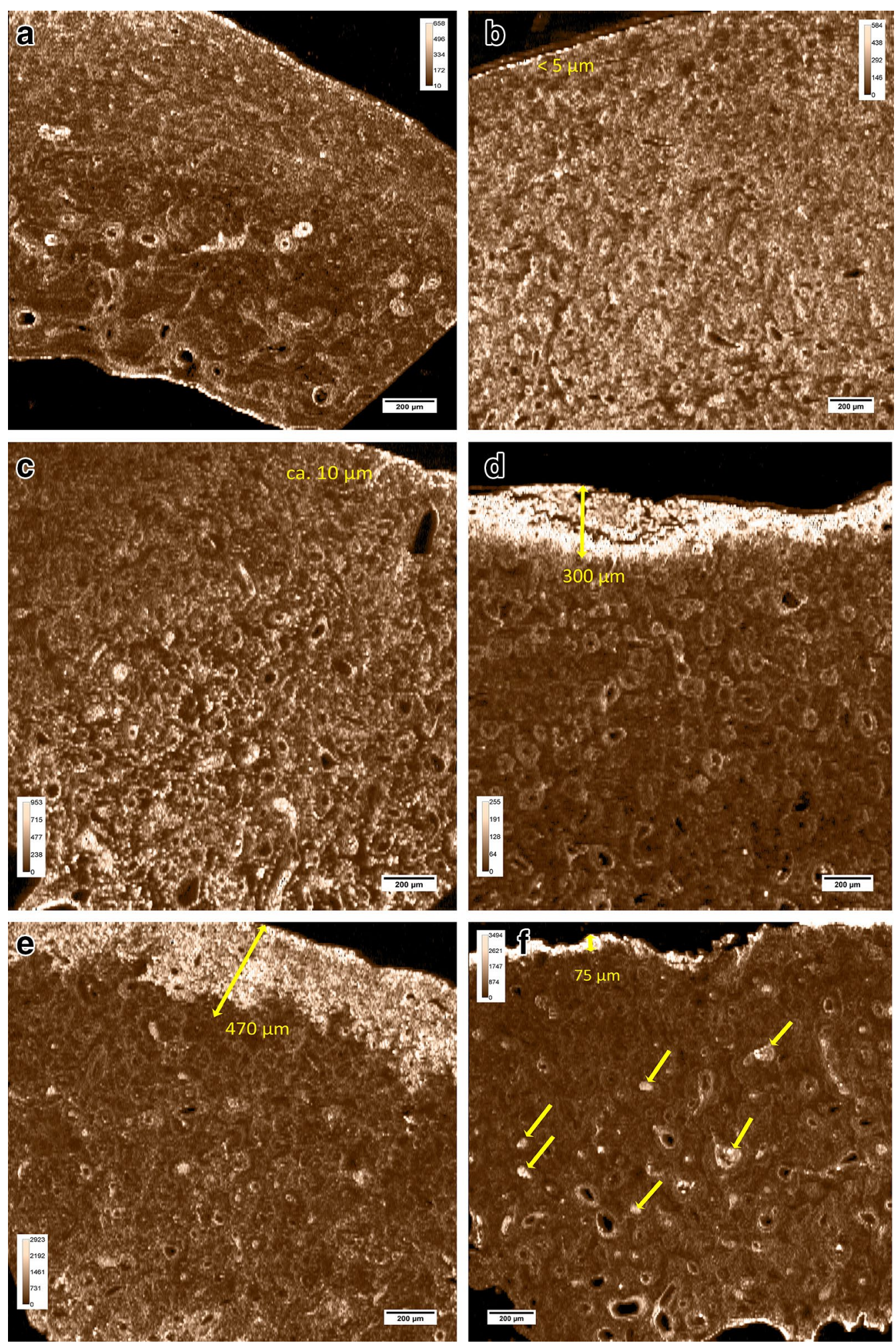

Fig. 2 Distribution of Sr in six individuals: a D35, a modern woman 29 years old; b K1147, an archaeological female skeleton ca. 38-48 years from Ribe; c A85, an archaeological male skeleton ca. 35-70 years from Svendborg; d K1029, an archaeological female skeleton ca. 37-47 years from Ribe; e K1256, an archaeological male skeleton ca. 45-55 years from Ribe; and $\mathbf{f}$ AG134, an archaeological female skeleton ca. 38-48 years from Svendborg. Data are absolute-calibrated to $\mu \mathrm{g} \mathrm{g}^{-1}$, shown in the insert as a colour scale. The scale bar is $200 \mu \mathrm{m}$. The beam size, and consequently the spatial resolution of the image is $10 \mu \mathrm{m}$ 

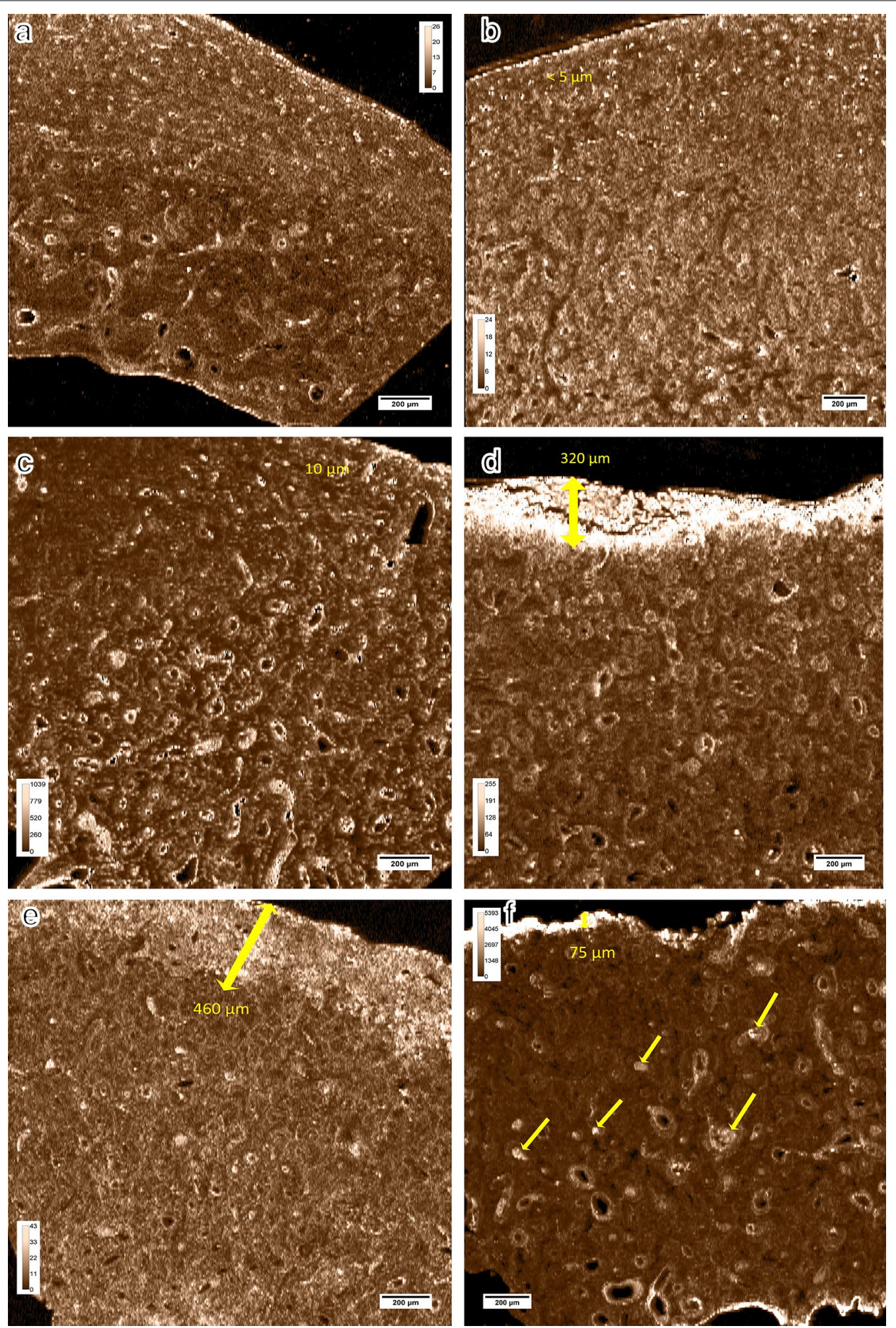

Fig. 3 Distribution of Ba in six individuals: a D35, modern; b K1147, archaeological; c A85, archaeological; d K1029, archaeological; e K1256, archaeological; and $\mathbf{f}$ AG134, archaeological. Data are absolute-calibrated to $\mu \mathrm{g} \mathrm{g}^{-1}$, shown in the insert as a colour scale. The scale bar is $200 \mu \mathrm{m}$. The beam size, and consequently the spatial resolution of the image is $10 \mu \mathrm{m}$ 

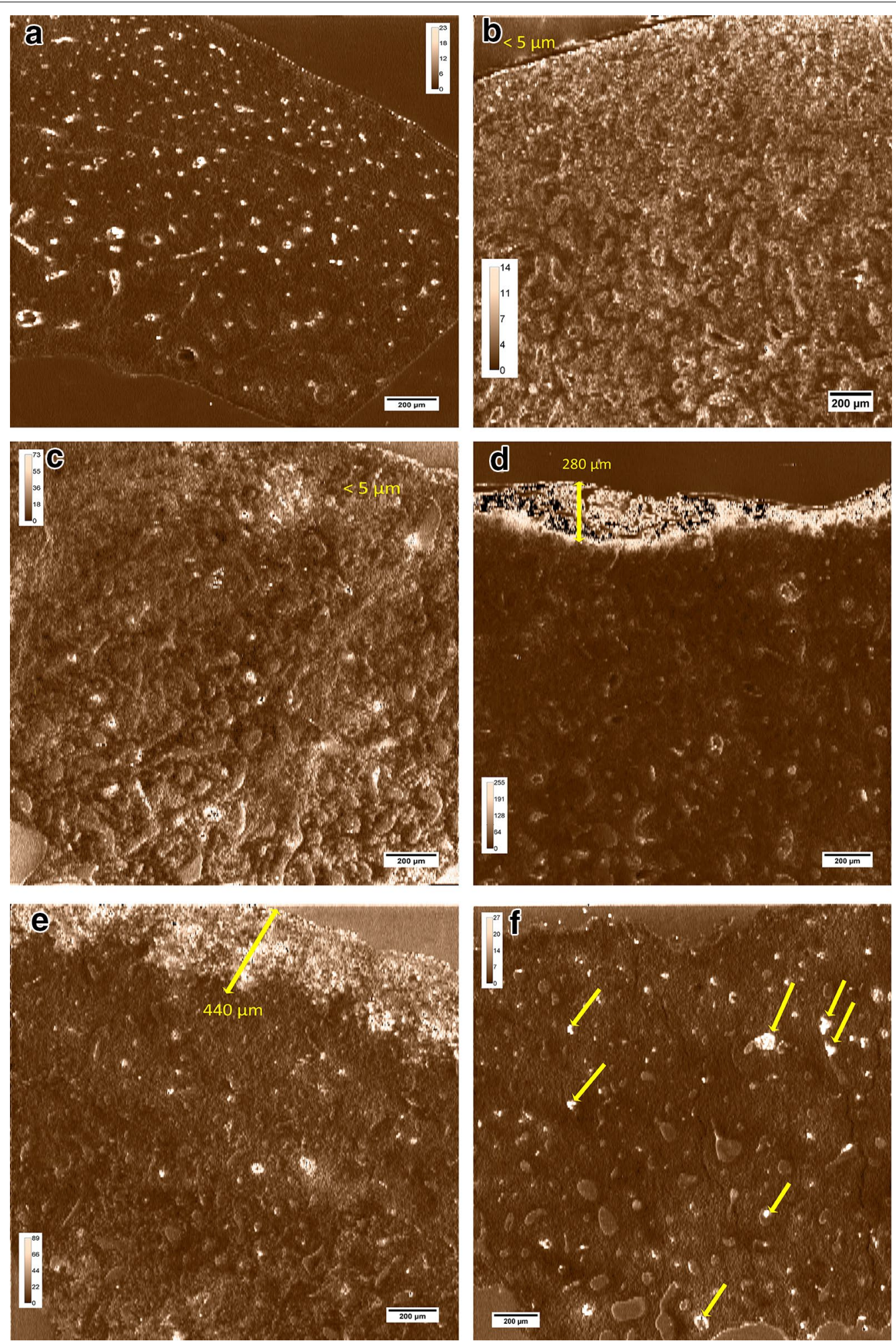

Fig. 4 Distribution of Cu in six individuals: a D35, modern; b K1147, archaeological; c A85, archaeological; d K1029, archaeological; e K1256, archaeological; and $\mathbf{f}$ AG134, archaeological. Data are absolute-calibrated to $\mu \mathrm{g} \mathrm{g}^{-1}$, shown in the insert as a colour scale. The scale bar is $200 \mu \mathrm{m}$. The beam size, and consequently the spatial resolution of the image is $10 \mu \mathrm{m}$ 

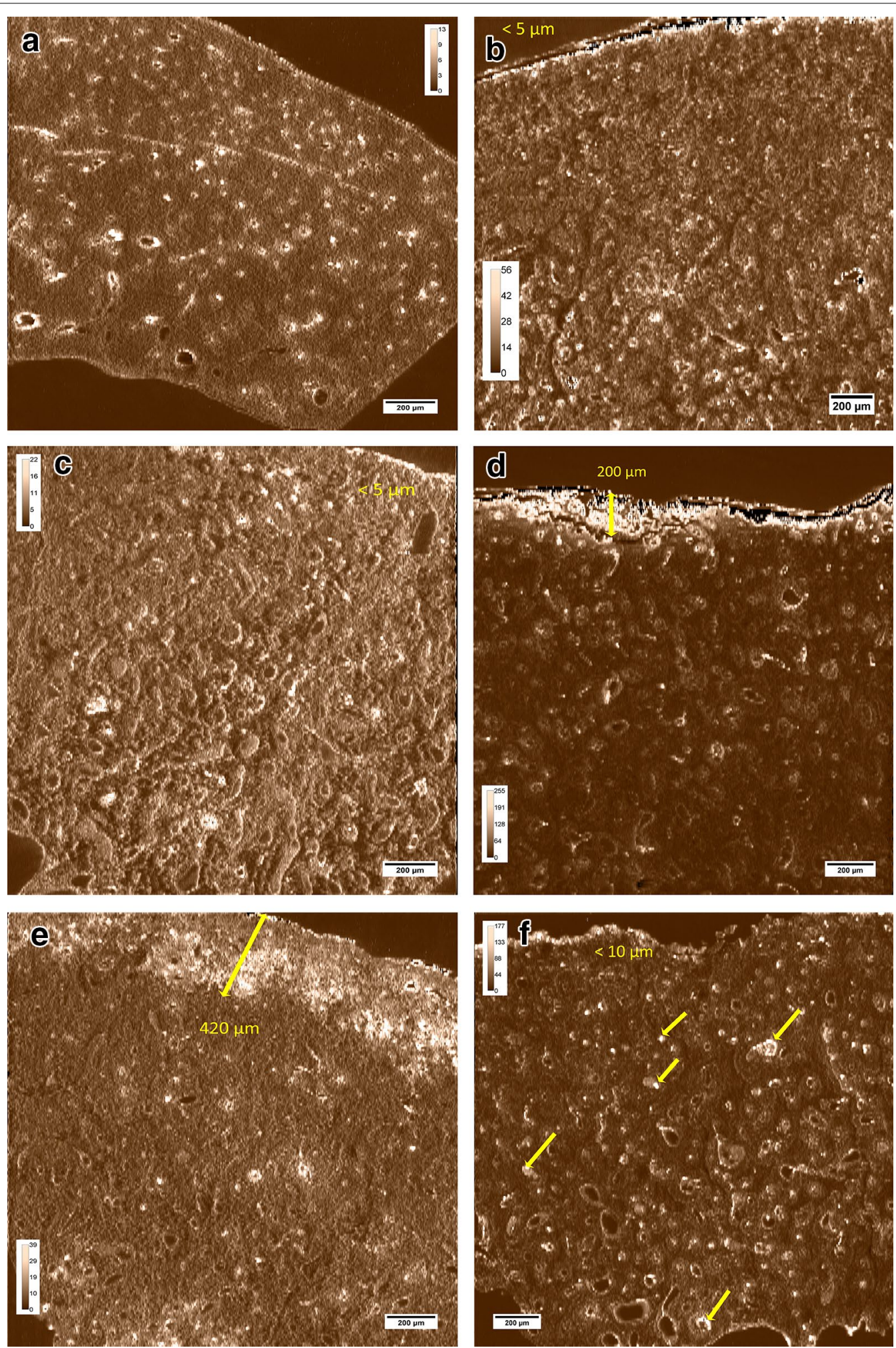

Fig. 5 Distribution of Pb in six individuals: a D35, modern; b K1147, archaeological; c A85, archaeological; d K1029, archaeological; e K1256, archaeological; and $\mathbf{f}$ AG134, archaeological. Data are absolute-calibrated to $\mu \mathrm{g} \mathrm{g}^{-1}$, shown in the insert as a colour scale. The scale bar is $200 \mu \mathrm{m}$. The beam size, and consequently the spatial resolution of the image is $10 \mu \mathrm{m}$ 

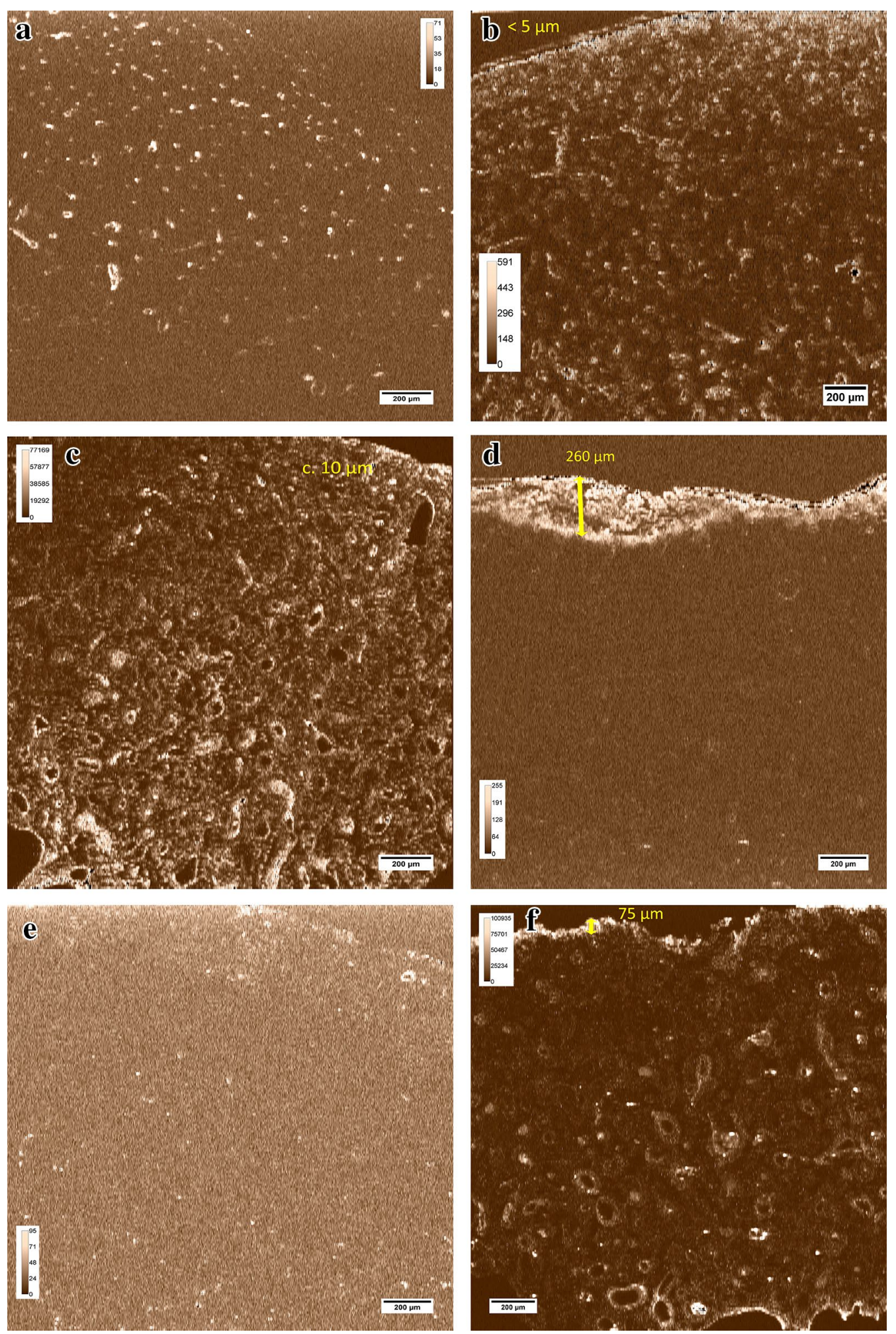

Fig. 6 Distribution of Fe in six individuals: a D35, modern; b K1147, archaeological; c A85, archaeological; d K1029, archaeological; e K1256, archaeological; and $\mathbf{f}$ AG134, archaeological. Data are absolute-calibrated to $\mu \mathrm{g} \mathrm{g}^{-1}$, shown in the insert as a colour scale. The scale bar is $200 \mu \mathrm{m}$. The beam size, and consequently the spatial resolution of the image is $10 \mu \mathrm{m}$ 

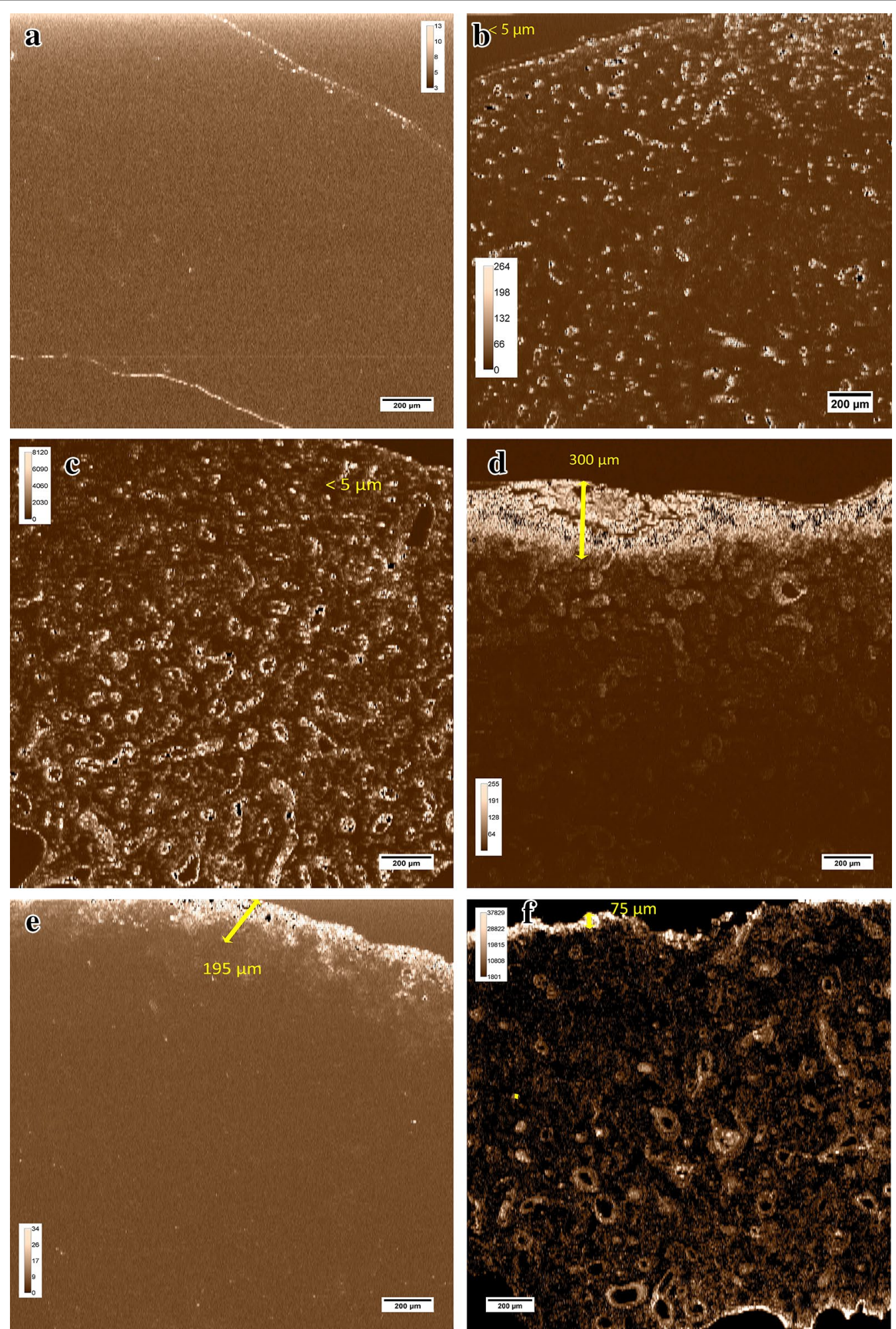

Fig. 7 Distribution of Mn in six individuals: a D35, modern; b K1147, archaeological; c A85, archaeological; d K1029, archaeological; e K1256, archaeological; and $\mathbf{f}$ AG134, archaeological. Data are absolute-calibrated to $\mu \mathrm{g} \mathrm{g}^{-1}$, shown in the insert as a colour scale. The scale bar is $200 \mu \mathrm{m}$. The beam size, and consequently the spatial resolution of the image is $10 \mu \mathrm{m}$ 
A surface enrichment of elements and individual osteons can be seen in many cross-sections. Structural details seen in the modern femur are also visible in the archaeological specimens. They indicate that much of the original bone microstructure remains intact in the archaeological femora. That alone, however, does not exclude the possibility that there has been chemical alteration through ion substitution in the inorganic fraction of bone.

The distribution of Sr characterized by LA-ICP-MS mapping is shown in Fig. 2. In the modern individual, there is a quite thin, but clearly visible, layer on the outer and inner surfaces of the cortical bone where the Sr concentration is distinctly higher than it is in the bone's interior (Fig. 2a). The width of the exterior Sr-enriched layer is estimated as less than $5 \mu \mathrm{m}$ (the laser beam diameter was $10 \mu \mathrm{m}$ ). Because this sample came from an autopsy performed shortly after death, there is no possibility of postinterment diagenetic processes related to exposure to soil or groundwater.

In Ribe K1147, the Sr distribution is similar to that of the modern individual (Fig. 2b). The Sr concentration is especially high on the bone's exterior, and the interior with readily visible osteons appears much like that of the modern individual. There are more visible osteons, however, consistent with an older age at death. Svendborg A85 also has a thin Sr-enriched rim, which extends about ca. $10 \mu \mathrm{m}$ into the bone (Fig. 2c). Strontium is enriched in many osteons. Haversian canals are mostly open, but several are plugged with what appears to be material deposited after death.

Diagenetic changes extend from the exterior into the cortical bone up to $300 \mu \mathrm{m}$ in $\mathrm{K} 1029$ and $470 \mu \mathrm{m}$ in K1256 from Ribe (Fig. 2d, e). Osteons beyond the degraded areas are visible in both specimens. A second skeleton from Svendborg, AG134, has an outer Sr invasion zone of ca. $75 \mu \mathrm{m}$ (Fig. 2f). In this specimen, approximately one-tenth of the Haversian canals are filled with Sr-rich diagenetic material, indicated by arrows in Fig. $2 \mathrm{f}$. In that respect, this individual is quite unusual in the initial 88 skeletons from which the analyzed sample was drawn.

The distributions of $\mathrm{Ba}$ in the six cross-sections are shown in Fig. 3. Once again, the modern sample and Ribe K1147 are similar (Fig. 3a, b). The outermost parts of these bones, to a depth no more than ca. $5 \mu \mathrm{m}$, are enriched in $\mathrm{Ba}$. Osteons within the two samples are readily visible. In Svendborg A85, the bone showing Ba enrichment extended to a maximum of ca. $10 \mu \mathrm{m}$ into the sample (Fig. 3c). All Haversian canals appear to be open, which is different from the Sr infilling. Much like what was seen for Sr, diagenetic changes indicated by high $\mathrm{Ba}$ concentrations form a distinct outer rind in Ribe K1029 and K1256 (Fig. 3d, e). The depths of these areas $-320 \mu \mathrm{m}$ and $460 \mu \mathrm{m}$ for $\mathrm{K} 1029$ and K1256, respectively-are similar to what is seen for Sr (Fig. 2d, e). In Svendborg AG134, there is a Ba invasion zone of ca. $75 \mu \mathrm{m}$ (Fig. 3f). About one-tenth of the Haversian canals, indicated by arrows in Fig. 3f, are filled with a diagenetic material rich in $\mathrm{Ba}$, like what was seen for $\mathrm{Sr}$.

Concentration scales for $\mathrm{Cu}$ in Fig. 4 are much different for the six individuals. The modern person, D35, and Svendborg AG134 have bulk $\mathrm{Cu}$ concentrations below LOQ $\left(<2.56 \mu \mathrm{g} \mathrm{g}^{-1}\right)$, so the concentration estimates in Fig. $4 \mathrm{a}, \mathrm{f}$ are semiquantitative because the LOQ is used as the bulk concentration when calibrating laser ablation measurements. The surface diagenesis of $\mathrm{Cu}$ extends $<5 \mu \mathrm{m}$ into the bone interior for D35, Ribe K1147, Svendborg A85, and Svendborg AG134, and 280 and $440 \mu \mathrm{m}$ in Ribe K1029 and K1256, respectively. In the modern individual, the $\mathrm{Cu}$ concentration in the bulk sample is less than LOQ, so a strict calibration of the LA-ICP-MS elemental map is not possible. However, for illustrative purposes we have used the LOQ of $2.56 \mu \mathrm{g} \mathrm{g}^{-1}$ as a calibration value in Fig. 4a, where the highest values obtained anywhere in the picture becomes $23 \mu \mathrm{g} \mathrm{g}^{-1}$. The little $\mathrm{Cu}$ that is present mostly coats the interior of Haversian canals (Fig. 4a). The Cu concentra-

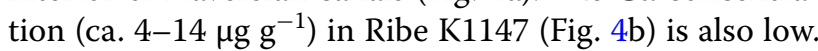
No external surface invasion zone is observable in $\mathrm{Cu}$ at the resolution of the laser ablation, and the $\mathrm{Cu}$ that is present is located in osteons. Much the same can be said for Svendborg A85, although the $\mathrm{Cu}$ concentration is somewhat higher, ranging from ca. 10 to $70 \mu^{g} g^{-1}$ (Fig. 4c). In contrast, the $\mathrm{Cu}$ concentration is especially high, up to $255 \mu \mathrm{g} \mathrm{g}^{-1}$, in the invasion zone that extends up to $280 \mu \mathrm{m}$ into the Ribe K1029 femur (Fig. 4d). Otherwise the interior of the bone appears much like that of Ribe K1147 and Svendborg A85 where osteons are readily visible. The zone of diagenetic change in Ribe K1256 was also thick relative to other samples, up to a maximum of $440 \mu \mathrm{m}$ (Fig. 4e). Svendborg AG134 differs from the others because there is no observable $\mathrm{Cu}$ invasion zone, but $\mathrm{Cu}$ is present in diagenetic material that fills some Haversian canals (arrows in Fig. 4f). Despite Cu being a component of the diagenetic infilling of the canals, the adjacent bony portions of the osteons are unaffected by the proximity of that element.

Laser ablation data for $\mathrm{Pb}$ are depicted in Fig. 5. Concentrations of $\mathrm{Pb}$ are low in the modern individual, D35, varying from 3 to $13 \mu \mathrm{g} \mathrm{g}^{-1}$. Some osteons are enriched in $\mathrm{Pb}$, and the same might be said about the bone's surface, although the resolution is insufficient to provide a clear picture. Two archaeological samples, Ribe K1147 and Svendborg A85, are similar to the modern bone, although $\mathrm{Pb}$ concentrations are a little higher (Fig. 5b and in particular Fig. 5c). In both of these bones, $\mathrm{a} \mathrm{Pb}$ 
enriched surface zone can be seen, although it is less than ca. $5 \mu \mathrm{m}$ thick. In Ribe K1029 and K1256, Pb invasion zones extend into the bone for up to 200 and $420 \mu \mathrm{m}$, respectively (Fig. 5d, e). In these two Ribe specimens, the bone interiors are unaffected by diagenesis. There is only a thin $\mathrm{Pb}$ invasion zone less than $10 \mu \mathrm{m}$ thick in Svendborg AG134, and a few Haversian canals are filled with a diagenetic material high in $\mathrm{Pb}$ (arrows in Fig. 5f). The osteons in this specimen are seemingly unaffected by diagenesis, even those where canals are packed with $\mathrm{Pb}$ enriched material.

The distributions of Fe in the six bone cross-sections are shown in Fig. 6. In the modern individual, D35, Fe is concentrated in Haversian canals (Fig. 6a). The Fe probably originated from blood in the vessels that once passed through these openings. The Fe distributions in two archaeological femora, Ribe K1147 and Svendborg A85, are similar to the modern sample, although concentration values are far higher, extending up to 590 and $77,000 \mu \mathrm{g} \mathrm{g}^{-1}$ for the Ribe and Svendborg bones, respectively. Outer $\mathrm{Fe}$ invasion zones are minimal in both of these archaeological bones (Fig. 6b, c). A Fe invasion zone extending to a depth of $260 \mu \mathrm{m}$ is apparent in Ribe K1029, although osteons are not visible (Fig. 6d). In Ribe K1256, no bony microstructure is seen in the Fe data (Fig. 6e). In that respect it is similar to the interior of Ribe K1029. Svendborg AG134 has a Fe invasion zone of ca. $75 \mu \mathrm{m}$, the bone immediately adjacent to Haversian canals in some osteons is enriched in $\mathrm{Fe}$, and diagenetic material high in Fe fills a few canals in AG134.

Figure 7 shows the distribution of $\mathrm{Mn}$ in the femoral cross-sections. The modern femur, D35, has quite low Mn concentrations, and the only enrichment visible is at the exterior and interior bone surfaces (Fig. 7a). Nothing can be seen of bone microstructure. In Ribe K1147 and Svendborg A85, invasion zones are not visible, and the $\mathrm{Mn}$ that is present is concentrated in osteons, especially around Haversian canals (Fig. 7b, c). In Ribe K1029 and K1256 there are notable zones of diagenetic change that are ca. 300 and $195 \mu \mathrm{m}$ thick, respectively (Fig. 7d, e). Yet despite relatively deep zones of diagenetic change, there is no evidence of similar Mn enrichment near the inner surfaces bordering the medullary cavities. In Svendborg AG134, there is an outer invasion zone of ca. $75 \mu \mathrm{m}$, and osteons and diagenetic material within Haversian canals are often enriched in Mn (Fig. 7f).

\section{Diffusion rates}

The depths of bone degradation in cross-sections analyzed by LA-ICP-MS are provided in Table 3 for Fe, Sr, $\mathrm{Ba}$, and $\mathrm{Pb}$, along with diffusion times estimated using Eq. 1. Diffusion times for Fe in all archaeological samples are less than 100 years. For Sr, they are less than
350 years. Those for $\mathrm{Ba}$ and $\mathrm{Pb}$, however, are much greater, reaching a maximum of 18,000 years for $\mathrm{Ba}$ and 3500 years for $\mathrm{Pb}$.

\section{Soil samples}

Average element concentrations in the Ribe soil samples do not deviate from the concentrations within the Ribe bones in a consistent manner: some are higher, whereas others are lower. For $\mathrm{Ca}, \mathrm{Zn}, \mathrm{Na}, \mathrm{Mg}$, and $\mathrm{Sr}$, the soil concentrations are lower than in bulk bone samples from $\mathrm{K} 1147$, K1029, and $\mathrm{K} 1256$. For $\mathrm{Ba}, \mathrm{Cu}, \mathrm{Pb}$ and Fe, the soil concentrations are higher than in the bones. For $\mathrm{Mn}$, the soil value is exceeded by that of K1029, but it is greater than the K1147 and K1256 concentrations.

\section{Discussion}

\section{Element concentrations and distributions}

For the most part, the bulk sample concentrations of the modern Danish individual, D35, are not out of line with much of what has been reported in studies of recent human bones (Table 4). Existing data, however, are difficult, if not impossible, to interpret at face value in terms of our findings, even when compact and trabecular bone are reported separately. That is because there is considerable variation in sample processing procedures; analytical methods and instrumentation; population diets and environments; sample age, sex, and health status; and the bones and the specific parts of them that were examined. Nevertheless, two elements, Fe and Mn, stand out as deviating from the general pattern, with Fe being more easily explained than Mn.

The Danish modern sample's Fe concentration was lower than what has been reported for recent skeletons elsewhere, although it is close to the lower bound of the concentration range for women and men from southwestern Poland (Silesia [79]). It is possible that higher Fe values in other studies resulted from some combination of the following: less stringent cleaning procedures, inclusion of some trabeculae with compact bone, or an older sample that included people tending toward an osteoporotic condition.

The concentration of $\mathrm{Mn}$ in the modern bone, D35, is higher than reported in most studies. However, it is within the $\mathrm{Mn}$ range for femoral head cortical bone from southwestern Polish (Silesian) females, and it is reasonably close to the median in that sample [79]. Perhaps the high Mn concentration in D35 resulted from some unknown exposure during the years immediately prior to her death. Human bone Mn concentrations can vary because of exposure, such as through an individual's occupation [94].

The ranges of values for modern individuals are of limited value as a basis for detecting a diagenetic effect in 
Table 3 Observed invasion zones and estimated diffusion times in years

\begin{tabular}{|c|c|c|c|c|c|}
\hline Lab designation & Field designation & Site & Element & Diffusion length $(\mu \mathrm{m})$ & $\begin{array}{l}\text { Diffusion } \\
\text { time } \\
\text { (years) }\end{array}$ \\
\hline KLR-10516 & K1147 & Ribe & $\mathrm{Mn}$ & $<5$ & NE \\
\hline KLR-10516 & K1147 & Ribe & $\mathrm{Fe}$ & $<5$ & 0 \\
\hline KLR-10516 & K1147 & Ribe & $\mathrm{Cu}$ & $<5$ & NE \\
\hline KLR-10516 & K1147 & Ribe & $\mathrm{Sr}$ & $<5$ & 0 \\
\hline KLR-10516 & K1147 & Ribe & $\mathrm{Ba}$ & $<5$ & 0 \\
\hline KLR-10516 & K1147 & Ribe & $\mathrm{Pb}$ & $<5$ & 0 \\
\hline KLR-8348 & A85 & Svendborg & $\mathrm{Mn}$ & $<5$ & 0 \\
\hline KLR-8348 & A85 & Svendborg & $\mathrm{Fe}$ & 10 & 0.1 \\
\hline KLR-8348 & A85 & Svendborg & $\mathrm{Cu}$ & $<5$ & 0 \\
\hline KLR-8348 & A85 & Svendborg & $\mathrm{Sr}$ & 10 & 0.2 \\
\hline KLR-8348 & A85 & Svendborg & $\mathrm{Ba}$ & 10 & 9 \\
\hline KLR-8348 & A85 & Svendborg & $\mathrm{Pb}$ & $<5$ & 0 \\
\hline KLR-10831 & K1029 & Ribe & $\mathrm{Mn}$ & 300 & $\mathrm{NE}$ \\
\hline KLR-10831 & K1029 & Ribe & $\mathrm{Fe}$ & 260 & 100 \\
\hline KLR-10831 & K1029 & Ribe & $\mathrm{Cu}$ & 280 & $\mathrm{NE}$ \\
\hline KLR-10831 & K1029 & Ribe & $\mathrm{Sr}$ & 300 & 140 \\
\hline KLR-10831 & K1029 & Ribe & $\mathrm{Ba}$ & 320 & 8700 \\
\hline KLR-10831 & K1029 & Ribe & $\mathrm{Pb}$ & 200 & 800 \\
\hline KLR-10810 & K1256 & Ribe & $\mathrm{Mn}$ & 195 & $\mathrm{NE}$ \\
\hline KLR-10810 & K1256 & Ribe & $\mathrm{Fe}$ & NA & $\mathrm{NE}$ \\
\hline KLR-10810 & K1256 & Ribe & $\mathrm{Cu}$ & 440 & $\mathrm{NE}$ \\
\hline KLR-10810 & K1256 & Ribe & $\mathrm{Sr}$ & 470 & 350 \\
\hline KLR-10810 & K1256 & Ribe & $\mathrm{Ba}$ & 460 & 18000 \\
\hline KLR-10810 & K1256 & Ribe & $\mathrm{Pb}$ & 420 & 3500 \\
\hline KLR-10236 & AG134 & Svendborg & $\mathrm{Mn}$ & 75 & $\mathrm{NE}$ \\
\hline KLR-10236 & AG134 & Svendborg & $\mathrm{Fe}$ & 75 & 8 \\
\hline KLR-10236 & AG134 & Svendborg & $\mathrm{Cu}$ & $<5$ & $\mathrm{NE}$ \\
\hline KLR-10236 & AG134 & Svendborg & $\mathrm{Sr}$ & 75 & 9 \\
\hline KLR-10236 & AG134 & Svendborg & $\mathrm{Ba}$ & 75 & 480 \\
\hline KLR-10236 & AG134 & Svendborg & $\mathrm{Pb}$ & 10 & 2 \\
\hline KLR-10977 & D35 & Modern & $\mathrm{Mn}$ & $<5$ & $\mathrm{NE}$ \\
\hline KLR-10977 & D35 & Modern & $\mathrm{Fe}$ & $<5$ & 0 \\
\hline KLR-10977 & D35 & Modern & $\mathrm{Cu}$ & $<5$ & $\mathrm{NE}$ \\
\hline KLR-10977 & D35 & Modern & $\mathrm{Sr}$ & $<5$ & 0 \\
\hline KLR-10977 & D35 & Modern & $\mathrm{Ba}$ & $<5$ & 0 \\
\hline KLR-10977 & D35 & Modern & $\mathrm{Pb}$ & $<5$ & 0 \\
\hline
\end{tabular}

One degraded area diffusion length was not acquired (NA), and diffusion times were not estimated (NE) for Mn and $\mathrm{Cu}$

archaeological bones, especially given uncertainty in the comparability of results, as mentioned above. It is nonetheless clear that some element concentrations for the archaeological bones are tightly clustered and are reasonably close to the modern Danish individual (Fig. 1). For those bones and elements, it is not possible to exclude the possibility that the primary signal is biogenic. In other individuals, there is a distinct diagenetic effect because the bulk sample results are very different from what might be expected in modern bone. Individuals such as Svendborg A85 and AG134 that have remarkably high Fe concentrations are obvious examples of diagenesis detectable from bulk sample results alone (Table 2).

Concentration cross-sections provide a better perspective on diagenesis. In most of the archaeological specimens, outer rims of element-enriched bone indicative of a diagenetic effect are readily visible (Figs. 2, 3, $4,5,6,7)$. Microstructural details in the distributions 


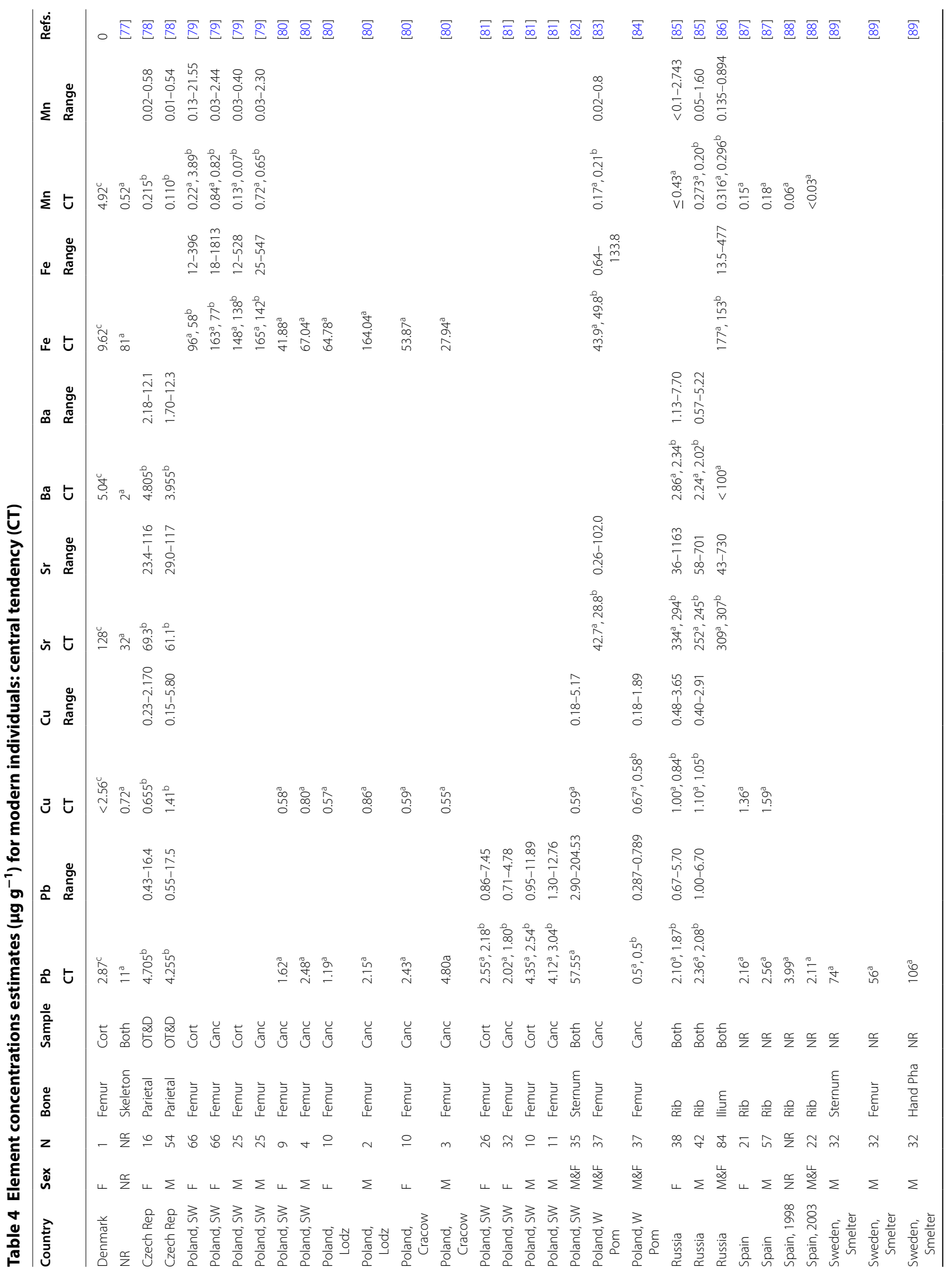




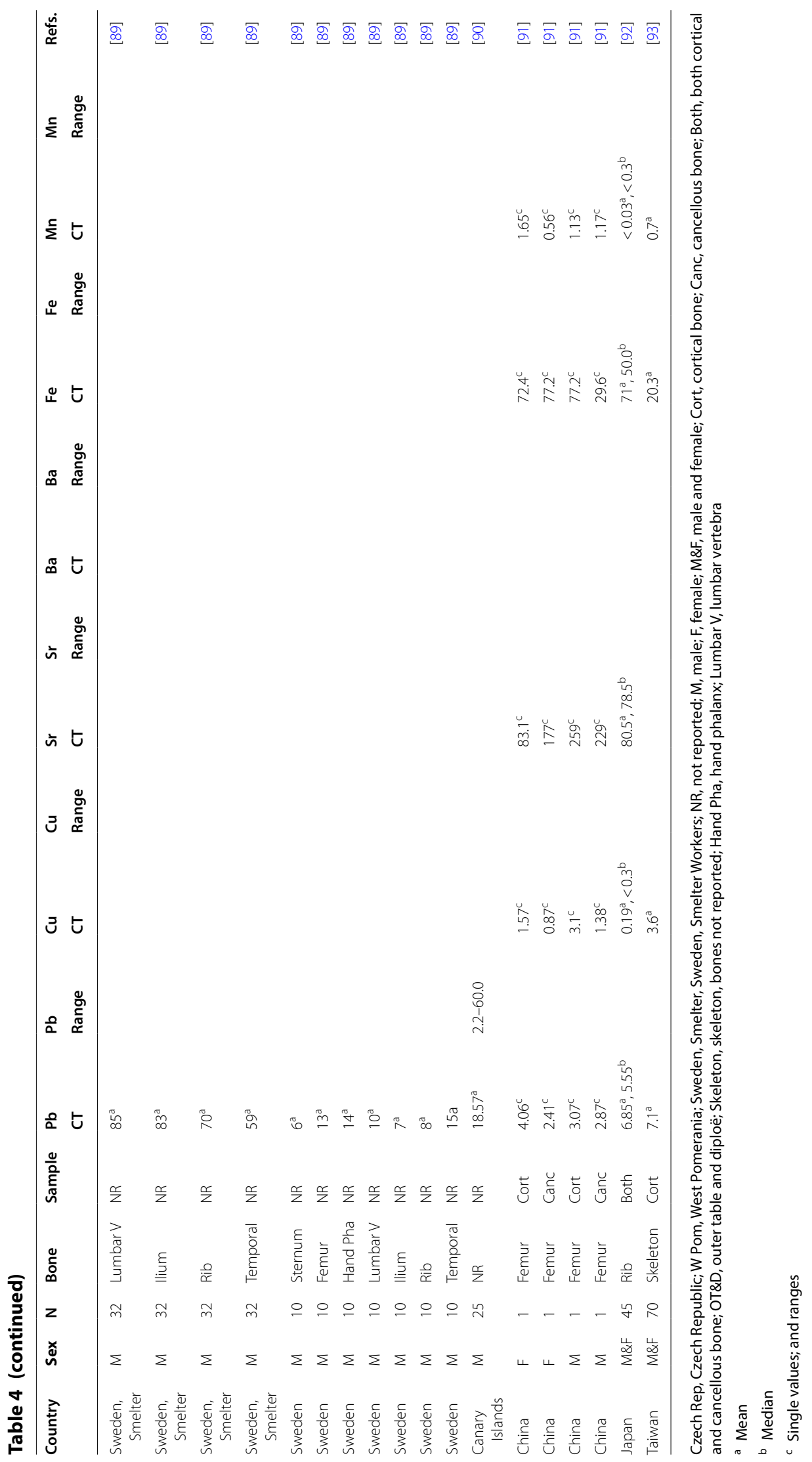


of elements within the bones can also be seen, consistent with what occurs in modern bone samples [43]. In some femora, material filling minute openings within the compact bone has an elemental composition that differs from the surrounding lamellar bone of osteons. That contrast is indicative of the retention of an antemortem chemical signal in the lamellar bone.

For $\mathrm{Sr}$, the archaeological bulk sample results are tightly clustered, and they are close to what was recorded for the modern individual. Outer rims of degraded bone, the thickest of which was no more than $500 \mu \mathrm{m}$, occur in bones buried for hundreds of years. In all of these specimens, microstructural details are still visible in the cortical bone interior. Taken together, these findings increase confidence that $\mathrm{Sr}$ from within compact bone retains a biogenic signal.

One noteworthy feature seen in these bones, including the modern specimen, is an enrichment in $\mathrm{Sr}$ concentrations at the external and internal (medullary) surfaces. We do not know why that might be the case, but it would appear that more than diagenesis is involved. Perhaps it is related to the presence of perforating (Sharpey's) fibers, which anchor the periosteum and endosteum by penetrating the underlying bone, and their subsequent mineralization [95-97].

Of the Ba bulk bone samples, three are tightly clustered and are not greatly different from the concentration in the modern individual. Two samples, however, are suspiciously high, with one being ca. 80 times greater than in the modern individual, and the other ca. 40 times as much. Perhaps these high bulk sample concentrations resulted from differences in diet because food varies widely in Ba content (see Fig. 8 and references in [29]). A more conservative interpretation would be that the notably high concentrations came about through diagenetic changes in the bones. In short, based on bulk sample chemistry it cannot be said with certainty whether the two outliers are largely a result of diagenesis or not. The cross-section mapping of element concentrations, however, indicates that in one of the two questionable specimens, Svendborg AG134, some Haversian canals are filled by a Ba-enriched material. The postmortem deposition of this material contributed to, and was perhaps largely responsible for, the high value for this individual. It is not immediately clear why the other Svendborg individual, A85, also has a high bulk sample Ba concentration, although it was lower than AG134. Perhaps A85 was also the subject of a postmortem infilling of openings in the part of the bone selected for the bulk sample, even though it was absent in the adjacent cross-section. That might have occurred if there was an undetected postmortem crack in the bone.
Nothing definitive can be said about archaeological bulk bone $\mathrm{Cu}$ concentrations relative to the modern individual because the estimated concentration was below LOQ. The $\mathrm{Cu}$ concentrations in four of the archaeological samples are greater than what has been reported for modern people (Tables 2, 4). Copper distributions in laser ablation cross-sections differ from those of $\mathrm{Sr}$ and $\mathrm{Ba}$. In Svendborg AG134, a Cu-enriched outer layer of bone is not present, although for $\mathrm{Sr}$ and Ba they are $75 \mu \mathrm{m}$ thick (Figs. 2f, 3f, 4f). A likely reason for this difference is that $\mathrm{Cu}$ simply was not present in the soil or groundwater in this burial location. The $\mathrm{Cu}$ concentration in this particular archaeological specimen was below LOQ, just like it was for the modern individual (Table 2). The situation is different for Ribe K1019 and K1256 where diagenetic alterations for all three elements penetrate the bone to roughly the same distance (Figs. $2 \mathrm{~d}$, e, 3d, e, 4d, e). The average $\mathrm{Cu}$ concentration for 78 soil samples from the Ribe cemetery (Table 2) were $141 \mu^{g g^{-1}}$, which is roughly comparable to the $80-90 \mu \mathrm{g} \mathrm{g}^{-1}$ in the diagenetic layer on the outermost surface of the K1256 bone. Thin zones of diagenetically altered bone are visible in Ribe K1147 and Svendborg A85 for $\mathrm{Cu}, \mathrm{Sr}$, and $\mathrm{Ba}$. Apparently, $\mathrm{Cu}$ usually behaves similarly to $\mathrm{Sr}$ and $\mathrm{Ba}$ when it comes in contact with long-buried bones, provided it is present in the surrounding soil or ground water in the first place.

All of the archaeological bones have higher $\mathrm{Pb}$ concentrations $\left(6-184 \mu \mathrm{g} \mathrm{g}^{-1}\right)$ than the modern individual $\left(2.87 \mu \mathrm{g} \mathrm{g}^{-1}\right)$. There is no particular reason to think that was a result of diagenesis. The archaeological samples are consistent with modern data, if one includes individuals who experienced environmental or occupational exposure to $\mathrm{Pb}$. Centuries ago northern Europeans were certainly exposed to $\mathrm{Pb}$ in their everyday lives, so it is not surprising that concentrations of $\mathrm{Pb}$ in their skeleton might be considered high by modern standards. In an earlier study of medieval Danish skeletons, the rural populations had an upper threshold value of $\mathrm{Pb}$ in cortical tissue of $5 \mu \mathrm{g} \mathrm{g}^{-1}$, but they ranged up to $1000 \mu \mathrm{g} \mathrm{g}^{-1}$ in urban populations [34]. Concentrations of $\mathrm{Pb}$ in femoral trabecular bone-because of the surface area, cancellous bone is more likely to undergo diagenesis than cortical bone-were not correlated with what was found in samples of the adjacent soil. In separate work with skeletons from Lindegaarden in Ribe, soil sample $\mathrm{Pb}$ concentrations did not correlate with those of adjacent bones [29]. Apparently $\mathrm{Pb}$ exposure for many Danes was greater several centuries ago than it has been in recent decades for the general population of Europe. Moreover, in the past it varied in an explicable manner according to settlement type.

Despite the generally higher concentrations of $\mathrm{Pb}$ in archaeological bones relative to the modern specimen, 
the LA-ICP-MS cross-sections show no obvious internal enrichment except for Svendborg AG134 where material in bone openings has a strong Pb signal (Fig. 5f). Diagenetically altered bone near the external surface, with Ribe K1029 and K1256 showing far thicker degraded zones than the other bones (Fig. $5 \mathrm{~d}$, e), is generally similar to what is seen in the other elements. In some of the archaeological specimens, notably Ribe K1029 and Svendborg AG134, it is possible to see Pb-enriched margins of Haversian canals and cement lines. That is consistent with the retention of a biogenic signal in the archaeological bones because the same distribution has been reported for modern specimens [43]. The Danish bones are not the only archaeological specimens where canal margins and cement lines have been shown in elemental concentration cross-sections to be enriched in $\mathrm{Pb}$ [41]. The retention of a biogenic signal, therefore, can be considered a general phenomenon, not one limited to unknown peculiarities of the present sample.

The existence of cement lines enriched with certain elements, in both modern and archaeological samples, is presumably related to their hypermineralized nature, as indicated by the Ca content of modern bones [98]. In short, much remains to be learned about bone chemistry, and to a certain extent archaeological bones can complement the findings of studies of modern specimens.

In two of the five archaeological specimens, Fe concentrations exceed the upper bound of published concentrations ranges; they are, in fact, soaring high (Tables 2, 4). There can be no doubt that diagenetic changes have taken place over centuries of burial for these two samples, Svendborg AG134 and A85. A marked difference can be seen in Fe concentrations in samples from different geographical places. The Fe concentrations in the two Svendborg specimens far exceed those of the Ribe skeletons. The archaeological bones present a varied picture in terms of Fe in the bone microstructure. No variation in Fe is visible in two Ribe specimens, K 1029 and K1256, whereas osteons with varying Fe concentrations can be seen in the third Ribe bone and those from Svendborg where Fe concentrations are quite high, K1147, A85, and AG134 (Fig. 6b-f). The main difference between Fe and the other elements in the outer diagenetically altered zones is found in Ribe K1256 where there is no readily apparent thick rim of degraded bone (Fig. 6e).

Taken together, the bulk samples and concentration cross-sections are consistent with diagenetic Fe being derived from percolating groundwater, which would vary by burial setting. That is reassuring because Fe was initially included in this study as an example of an element where a diagenetic signal could be expected. Postmortem alterations of bone probably occur through the precipitation of $\mathrm{Fe}^{3+}$ from soluble anoxic $\mathrm{Fe}^{2+}$.
The two Svendborg samples and Ribe K1029 have quite high Mn concentrations, whereas that of Ribe K1147 is not as extreme (Table 2). One cannot avoid the conclusion that there was postmortem enrichment of $\mathrm{Mn}$ in all four femora. Only Ribe K1256 falls within a Mn range reported for a modern sample, females from southwestern Poland (Silesia), although the concentration is still high relative to what is generally seen [79]. The Mn and Fe values in this Ribe specimen-the Fe concentration is much lower than in the other four archaeological femora-suggest that the concentrations of these two elements are not always a product of diagenesis, despite the consensus in the field $[6-8,28-31,38,39,56-58]$. It is not immediately apparent why the burial environment contributed to $\mathrm{Mn}$ and Fe concentrations that are more reasonable than those of the other specimens.

In the concentration cross-sections, there are thin areas of Mn enrichment in the modern bone, D35 (Fig. 7a). That is similar to what is seen in the Sr cross-section, raising the possibility that a similar process is involved. For the archaeological femora, the outer portions of the $\mathrm{Mn}$ cross-sections are generally similar to those of the other elements. Enrichment zones are thin in Ribe K1147 and Svendborg A85. They are thick in Ribe K1029 and K1256, except for Fe in K1256 (Fig. 6e). The outer enriched zones in Svendborg AG134 are hardly noticeable for $\mathrm{Cu}$ and $\mathrm{Pb}$, and extend only ca. $75 \mu \mathrm{m}$ into the interior for $\mathrm{Sr}, \mathrm{Ba}$, $\mathrm{Fe}$, and Mn. Much like what was found for Fe, little if any internal microstructure is observable for $\mathrm{Mn}$ in D35, Ribe K1029, and Ribe K1256, whereas osteons are visible in Ribe K1147, Svendborg A85, and AG134. In that respect, $\mathrm{Mn}$ and Fe behave similarly.

\section{The nature of diagenesis}

Four different ways of invasion into buried compact bone can be envisaged for elements, and sometimes particles. They include: (1) diffusion from the periosteal or endosteal surfaces resulting in an alteration of the crystalline matrix; (2) diffusion via Haversian and Volkmann's canals; (3) an infilling of original (Haversian and Volkmann's canals) or postmortem openings (e.g., fungi tunnels and cracks); and (4) a physical or chemical breakdown of the exterior surface, leaving an outer porous layer that is susceptible to invasion by elements, depending on their solubility in the surrounding environment.

Diffusion times estimated from LA-ICP-MS crosssections are not as large as might be expected for Fe and $\mathrm{Sr}$, as they are all $\leq 100$ or $\leq 350$ years for those two elements, respectively. Several estimated diffusion times for $\mathrm{Ba}$ and $\mathrm{Pb}$ are implausibly high, being up to 18,000 years for $\mathrm{Ba}$ and 3500 years for $\mathrm{Pb}$. Yet for all elements, some of the estimated diffusion times are zero years in skeletons buried for centuries. Considering the well-characterized 
context of these burials, their dating cannot be far from the mark. Inconsistency among the estimates and the magnitude of some of them leads to two conclusions. Elemental diffusion in cortical bone as a general diagenetic pathway is inconsistent with what is observed for the archaeological specimens, a conclusion similar to that of an earlier experimental study [76]. The use of a single formula to estimate diffusion rates fails to accommodate the variation that exists among specimens and burial environments that presumably affects postmortem alterations in bone chemistry.

The second possibility, diffusion within Haversian and Volkmann's canals, should result in exponentially decreasing concentrations extending away from a majority of the canals. The cross-sections in Figs. 2, 3, 4, 5, 6 and 7 where outer element-enriched zones are clearly distinguishable from the interiors of the bones are not consistent with this possibility.

Material filling Haversian canals or coating their margins in Svendborg AG134 is consistent with the third possibility for the postmortem alteration of bone. All of the elements examined-Sr, $\mathrm{Ba}, \mathrm{Cu}, \mathrm{Pb}, \mathrm{Mn}$, and Fe (Figs. 2f, 3f, 4f, 5f, 6f, 7f)-have higher concentrations in the foreign deposits than in the surrounding bone. For the rest of the archaeological specimens, similar infilling is either absent or only slightly expressed. Complete or partial infilling of the Haversian channels with material high in one or more elements will, of course, influence the trace element concentrations when a bulk sample is analyzed. That is precisely the reason high-resolution LA-ICP-MS plots are examined: foreign material must first be identified and then chemically characterized. The possibility of this sort of contamination calls for a screening of bulk chemistry data for outliers in a suite of elements, as described in recommendations for sample handling provided below.

Mechanical or chemical breakdown of the outer bone surface, allowing chemical species to infiltrate the degraded bone, is indicated by the archaeological specimens. Some individuals show no such breakdown, or the degraded zones are quite thin. They naturally include the modern individual, D35, whose femur was never buried, but also Ribe K1147 and Svendborg A85. A moderate amount of degraded bone extends $10-75 \mu \mathrm{m}$ into the cortex of Svendborg AG134, except for an absence of $\mathrm{Cu}$. Interestingly, this is the specimen where elementally enriched material partly or completely filled openings in the bone's interior. Thicker degraded zones are visible in Ribe K1029 and K1256 where they extend up to $320 \mu \mathrm{m}$ and $470 \mu \mathrm{m}$, respectively.

To the extent that bones from two parts of Denmark are representative of archaeological specimens buried for a long time-for these specimens, several centuries-a mechanical or chemical breakdown of their surfaces permits the invasion of $\mathrm{Sr}, \mathrm{Ba}, \mathrm{Cu}, \mathrm{Pb}, \mathrm{Mn}$, and $\mathrm{Fe}$ to as much as about a half millimetre. Degraded areas in some specimens are absent, which must have to do with local soil conditions, such as the degree of anoxia and possibly variation in soil $\mathrm{pH}$. By local, we mean quite localized soil conditions because femora from the same cemetery show different amounts of diagenetic change.

For all of the medieval to early modern Danish skeletons, a biogenic signal appears to be retained in the inner portion of the cortical bone, as shown by bulk sampling and, especially, bone cross-section imaging. It should be noted, once again, that these skeletons have been selected out of 88 skeletons to span the entire range of diagenetic change. This finding is consistent with a study of twentieth century bones buried in different environmental settings [62]. Thus, with due caution it appears that studies of the elemental composition of bones buried for many centuries, and perhaps much longer, can be used effectively in archaeological studies of past diets and patterns of movement over a lifetime.

\section{Recommended sample pre-treatment}

The following is recommended to secure reliable data from bulk bone samples dating to the medieval and early modern periods from Denmark, and presumably elsewhere as well. The four recommended steps include the possibility of repeated examinations of data quality as analyses move forward.

First, and most importantly, the outer $1 \mathrm{~mm}$ of bone should be mechanically removed. That amount of bone is twice what is necessary to remove the degraded material in the archaeological specimens examined here. The outer layer of bone can be removed with a Dremel drill, or its equivalent. Working surfaces and tools must be properly cleaned, which includes rinsing in clean water (e.g., MilliQ). For Hg analyses, the saw blades or drill bits that come in contact with bone should also be heated in an ethanol flame.

Second, the acquired bulk sample trace element data should be examined to identify outliers.

Third, the outliers should be sampled again by removing a block of cortical bone sufficient for a ca. $5 \times 5 \mathrm{~mm}$ cross-section. The block should include the bone's exterior, and not have any visible signs of damage such as postmortem cracks. The cross-section should be analyzed by LA-ICP-MS, or a similar trace element mapping technique. Multiple elements should be examined to detect evidence of diagenesis-for example, to determine if antemortem or postmortem openings are clogged with foreign material. That is true even if only one element, say $\mathrm{Pb}$, is of interest because different elements can provide different perspectives on diagenetic processes in single 
specimens, as shown in this study. If there is reason to question the reliability of the results, much like those for Svendborg AG134, the specimen should not be used in analyses that rely on bulk bone samples.

Fourth, the process should be repeated if there are additional outliers found during subsequent data analyses. One would do so through LA-ICP-MS, or similar techniques, to assess the degree to which bone microstructure can be visualized through the concentrations of various elements.

The focus here on outliers is related to how research questions, hence data analyses, tend to be structured. Often the researcher's intent is to identify outliers under the assumption that these individuals would be from places some distance away from where they were buried. Conclusions are usually based on these putatively nonlocal people, not on the general tendency of the majority of the individuals examined. As much depends on reliably identifying these outliers, they should be the subject of special scrutiny.

Moving forward in the stepwise fashion outlined above accomplishes two purposes. It helps to ensure that reliable results are obtained, and it does so in a cost-efficient manner. That is accomplished by first screening samples through bulk analyses, and then examining outliers to see if the results are affected by diagenetic changes in the analyzed material. By reducing the number of specimens examined through the LA-ICP-MS procedure, a screening process that involves specially dedicated equipment and time-consuming analyses is reduced to a manageable level.

\section{Conclusions}

Analyses of cortical bone cross-sections with LA-ICPMS of femora from one modern and five archaeological individuals illustrate the extent and nature of diagenesis in medieval to early modern skeletons from Denmark. Two types of diagenetic changes occurred. The most frequent is an invasion by various elements into the outer parts of compact bone, and it is observed to extend no more than $470 \mu \mathrm{m}$ ( $\mathrm{Sr}$ in Ribe K1256). In some samples, no invasion zones are observable, despite several centuries of burial. These results point toward a precipitation of elements from ground water in physically or chemically degraded bone where the hydroxyapatite had lost some of its original structure. Bone microstructure, specifically osteons, are generally visible except where obscured by a degradation of the surface bone.

In one specimen, Svendborg AG134, there is a second type of diagenetic change. A foreign material rich in the analyzed elements fills the Haversian canals originally present in the bone. The bone of osteons immediately adjacent to these deposits is seemingly unaffected by diagenesis.
That is, this bone does not have elevated concentrations of the same elements as the material that made its way into the compact bone.

Removing the outer $1 \mathrm{~mm}$ of cortical bone will eliminate the effect of diagenesis for most medieval to early modern Danish specimens, making it possible to obtain reliable biogenic signals. Doing so, however, will not always result in a satisfactory sample. That is true of Svendborg AG134 with element-enriched material in openings within the bone. For that specimen, the removal of the outer $1 \mathrm{~mm}-$ or, for that matter, any amount of surface bone-will not decontaminate the sample sufficiently for analyses based on bulk samples. For that reason, intact pieces of bone from all bulk bone outliers should be examined with a LA-ICP-MS procedure before the results of analyses based on bulk bone samples are accepted at face value.

\section{Acknowledgements}

Permission to access samples from Ribe and Svendborg was kindly given by Morten Søvsø and Per Orla Thomsen. Financial support by the VELUX Foundation and the Independent Research Fund Denmark is gratefully acknowledged. Laboratory technician Pia Klingenberg Haussmann helped with the laboratory aspect of the work. Constructive reviews from anonymous reviewers are greatly appreciated.

\section{Authors' contributions}

Conceived and designed the experiments: KLR. Performed the experiments: KLR and LS. Analyzed the data: KLR and LS. Contributed to the anthropological and laboratory components of the work, including the interpretation of results and acquisition of references: KLR, LS, JLB, JLT, NL, and GRM. Wrote the paper, with comments from other participants: KLR and GRM. The paper was approved by all authors. All authors read and approved the final manuscript.

\section{Funding}

The present work has been funded by Velux Fonden (VELUX 32089) and Det Frie Forskningsråd (DFF-6107-00284).

Availability of data and materials

Data are available upon request from the authors.

Ethics approval and consent to participate

Approval was given by the Institute of Forensic Medicine at the University of Southern Denmark for sampling the modern femur. Sampling took place three decades ago, and it followed the rules at the time for human tissue sampling in forensic autopsies. No permission was required from next-of-kin.

\section{Competing interests}

The authors declare that they have no competing interests.

\section{Author details}

${ }^{1}$ Cultural Heritage and Archaeometric Research Team (CHART), Department of Physics, Chemistry and Pharmacy, University of Southern Denmark, Campusvej 55, 5230 Odense M, Denmark. ${ }^{2}$ Department of Anthropology, Pennsylvania State University, University Park, PA 16802, USA. ${ }^{3}$ Laboratory of Biological Anthropology, Institute of Forensic Medicine, University of Copenhagen, Blegdamsvej 3, 2200 Copenhagen, Denmark. ${ }^{4}$ Institute of Forensic Medicine, University of Southern Denmark, J. B. Winsløws Vej 17, 5000 Odense C, Denmark. ${ }^{5}$ Department of Anthropology (ADBOU), Institute of Forensic Medicine, University of Southern Denmark, Lucernemarken 20, 5260 Odense, Denmark.

Received: 3 February 2019 Accepted: 17 June 2019

Published online: 27 June 2019 


\section{References}

1. Hedges REM. Bone diagenesis: an overview of processes. Archaeometry. 2002;44:319-28.

2. Reynard B, Balter $V$. Trace elements and their isotopes in bones and teeth: diet, environments, diagenesis, and dating of archeological and paleontological samples. Palaeogeogr Palaeoclimatol Palaeoecol. 2014;416:4-16.

3. Smith Cl, Nielsen-Marsh CM, Jans MME, Collins MJ. Bone diagenesis in the European Holocene I: patterns and mechanisms. J Archaeol Sci. 2007:34:1485-93.

4. Smith $\mathrm{Cl}$, Craig OE, Prigodich RV, Nielsen-Marsh CM, Jans MME, Vermeer C, Collins MJ. Diagenesis and survival of osteocalcin in archaeological bone. J Archaeol Sci. 2005:32:105-13.

5. Burton $\mathrm{JH}$, Price TD. The ratio of barium to strontium as a paleodietary indicator of consumption of marine resources. J Archaeol Sci. 1990;17:547-57

6. Hancock RGV, Grynpas MD, Alpert B. Are archaeological bones similar to modern bones? An INAA assessment. J Radioanal Nucl Chem. 1987;110:283-91.

7. Lambert JB, Szpunar CB, Buikstra JE. Chemical analysis of excavated human bone from Middle and Late Woodland sites. Archaeometry. 1979;21:115-29.

8. Lambert JB, Vlasak SM, Thometz AC, Buikstra JE. A comparative study of the chemical analysis of ribs and femurs in Woodland populations. Am J Phys Anthropol. 1982;59:289-94

9. Nelson BK, DeNiro MJ, Schoeninger MJ, De Paolo DJ. Effects of diagenesis on strontium, carbon, nitrogen and oxygen concentration and isotopic composition of bone. Geochim Cosmochim Acta. 1986:50:1941-9.

10. Price TD. Late Archaic subsistence in the midwestern United States. J Hum Evol. 1985;14:449-59.

11. Price TD, Schoeninger MJ, Armelagos GJ. Bone chemistry and past behaviour: an overview. J Hum Evol. 1985:14:419-47.

12. Price TD, Blitz J, Burton J, Ezzo JA. Diagenesis in prehistoric bone: problems and solutions. J Archaeol Sci. 1992;19:513-29.

13. Schoeninger MJ. Diet and status at Chalcatzingo: some empirical and technical aspects of strontium analysis. Am J Phys Anthropol. 1979;51:295-310.

14. Schoeninger MJ. Diet and the evolution of modern human form in the Middle East. Am J Phys Anthropol. 1982;58:37-52.

15. Sealy JC, Sillen A. Sr and Sr/Ca in marine and terrestrial foodwebs in the southwestern cape, South Africa. J Archaeol Sci. 1988;15:425-38.

16. Sillen A, Kavanagh M. Strontium and paleodietary research: a review. Yearb Phys Anthropol. 1982;25:67-90.

17. Toots $H$, Voorhies MR. Strontium in fossil bones and the reconstruction of food chains. Science. 1965;149:854-5.

18. Bentley RA. Strontium isotopes from the earth to the archaeological skeleton: a review. J Archaeol Method Theory. 2006;13:135-87.

19. DeNiro MJ, Epstein S. Influence of diet on the distribution of nitrogen isotopes in animals. Geochim Cosmochim Acta. 1981;45:341-51.

20. Lee-Thorp JA. On isotopes and old bones. Archaeometry. 2008;50:925-50.

21. Makarewicz CA, Sealy J. Dietary reconstruction, mobility, and the analysis of ancient skeletal tissues: expanding the prospects of stable isotope research in archaeology. J Archaeol Sci. 2015;56:146-58.

22. Price TD, Burton JH, Bentley RA. The characterization of biologically available strontium isotope ratios for the study of prehistoric migration. Archaeometry. 2002;44:117-35.

23. Schoeninger MJ. Stable isotope analyses and the evolution of human diets. Ann Rev Anthropol. 2014;43:413-30.

24. Schoeninger MJ, Moore K. Bone stable isotope studies in archaeology. J World Prehist. 1992;6:247-96.

25. Schwarcz HP, Schoeninger MJ. Stable isotope analyses in human nutritional ecology. Yearb Phys Anthropol. 1991;34:283-321.

26. Knudson KJ, Price TD. Utility of multiple chemical techniques in archaeological residential mobility studies: case studies from Tiwanaku- and Chiribaya-affilated sites in the Andes. Am J Phys Anthropol. 2007;132:25-39.

27. Lösch S, Moghaddam N, Grossschmidt K, Risser DU. Kanz F (2014) Stable isotope and trace element studies on gladiators and contemporary Romans from Ephesus (Turkey, 2nd and 3rd ct AD) —implications for differences in diet. PLOS ONE. 2014;9:e110489.

28. Rasmussen KL, Skytte L, Pilekær C, Lauritsen A, Boldsen JL, Leth PM, et al. The distribution of mercury and other trace elements in the bones of two human individuals from medieval Denmark—the chemical life history hypothesis. Herit Sci. 2013;1:10.

29. Rasmussen KL, Skytte L, D'imporzano P, Thomsen PO, Søvsø M, Boldsen \lrcorner . On the distribution of trace element concentrations in multiple bone elements in 10 Danish medieval and post-medieval individuals. Am J Phys Anthropol. 2017;162:90-102.

30. Skytte L, Rasmussen KL. Sampling strategy and analysis of trace element concentrations by inductively coupled plasma mass spectroscopy on medieval human bones - the concept of chemical life history. Rapid Commun Mass Spectrom. 2013;27:1591-9.

31. Torino M, Boldsen JL, Tarp P, Rasmussen KL, Skytte L, Nielsen L, et al. Convento di San Francesco a Folloni: the function of a medieval Franciscan friary seen through the burials. Herit Sci. 2015;3:27.

32. Kępa M, Kozlowski T, Szostek K, Drozd A, Walas S, Mrowiec H. Analysis of mercury levels in historical bone material from syphilitic subjects-pilot studies. Anthrop Anz. 2012;69:367-77.

33. Rasmussen KL, Boldsen JL, Kristensen HK, Skytte L, Hansen KL, Mølholm L, Eriksen KMF. Mercury levels in Danish medieval human bones. J Archaeol Sci. 2008;35:2295-306.

34. Rasmussen KL, Skytte L, Jensen AJ, Boldsen JL. Comparison of mercury and lead levels in the bones of rural and urban populations in southern Denmark and northern Germany during the Middle Ages. J Archaeol Sci Rep. 2015;3:358-70.

35. Schroeder H, Shuler KA, Chenery SR. Childhood lead exposure in an enslaved African community in Barbados: implications for birthplace and health status. Am J Phys Anthropol. 2013;150:203-9.

36. Elliott TA, Grime GW. Examining the diagenetic alteration of human bone material from a range of archaeological burial sites using nuclear microscopy. Nucl Instrum Methods Phys Res B. 1993;77:537-47.

37. Guimarães D, Dias AA, Carvalho M, Carvalho ML, Santos JP, Henriques FR, Curate F, Pessanha S. Quantitative determinations and imaging in different structures of buried human bones from the XVIII-XIXth centuries by energy dispersive $\mathrm{X}$-ray fluorescence-post-mortem evaluation. Talanta. 2016;155:107-15

38. Kuczumow A, Cukrowska E, Stachnuik A, Gawęda R, Mroczka R, Paszkowicz W, et al. Investigation of chemical changes in bone material from South Africa fossil hominid deposits. J Archaeol Sci. 2010;37:107-15.

39. Lambert JB, Vlasak Simpson S, Buikstra JE, Hanson D. Electron microprobe analysis of elemental distribution in excavated human femurs. Am J Phys Anthropol. 1983:62:409-23.

40. Lambert JB, Simpson SV, Szpunar CB, Buikstra JE. Copper and barium as dietary discriminates: the effects of diagenesis. Archaeometry. 1984;26:131-8.

41. Swanston T, Varney T, Coulthard I, Feng R, Bewer B, Murphy R, et al. Element localization in archaeological bone using synchrontron radiation $X$-ray fluorescence: identification of biogenic uptake. J Archaeol Sci. 2012;39:2409-13.

42. Koenig AE, Rogers RR, Trueman CN. Visualizing fossilization using laser ablation-inductively coupled plasma-mass spectrometry maps of trace elements in late Cretaceous bones. Geology. 2009;37:511-4.

43. Pemmer B, Roschger A, Wastl A, Hofstaetter JG, Wobrauschek P, Simon R, et al. Spatial distribution of the trace elements zinc, strontium and lead in human bone tissue. Bone. 2013:57:184-93.

44. Dal Sasso G, Maritan L, Usai D, Angelini I, Artioli G. Bone diagenesis at the micro-scale: bone alteration patterns during multiple burial phases at $\mathrm{Al}$ Khiday (Khartoum, Sudan) between the early Holocene and the II century AD. Palaeogeogr Palaeoclimatol Palaeoecol. 2014;416:30-42.

45. Booth TJ. An investigation into the relationship between funerary treatment and bacterial bioerosion in European archaeological human bone. Archaeometry. 2016;58:484-99.

46. Fernández-Jalvo Y, Andrews P, Pesquero D, Smith C, Marín-Monfort D, Sánchez B, et al. Early bone diagenesis in temperate environments part I: surface features and histology. Palaeogeogr Palaeoclimatol Palaeoecol. 2010;288:62-81.

47. Hackett CJ. Microscopical focal destruction (tunnels) in exhumed human bones. Med Sci Law. 1981;21:243-65.

48. Hanson DB, Buikstra JE. Histomorphological alteration in buried human bone from the lower Illinois valley: implications for palaeodietary research. J Archaeol Sci. 1987;14:549-63. 
49. Kendall C, Eriksen AMH, Kontopoulos I, Collins MJ, Turner-Walker G. Diagenesis of archaeological bone and tooth. Palaeogeogr Palaeoclimatol Palaeoecol. 2018;491:21-37.

50. Müller K, Chadefaux C, Thomas N, Reiche I. Microbial attack of archaeological bones versus high concentrations of heavy metals in the burial environment. A case study of animal bones from a mediaeval copper workshop in Paris. Palaeogeogr Palaeoclimatol Palaeoecol. 2011;310:39-51

51. Jans MME, Kars $\mathrm{H}$, Nielsen-Marsh $\mathrm{CM}$, Smith $\mathrm{Cl}$, Nord AG, Arthur $\mathrm{P}$, et al. In situ preservation of archaeological bone: a histological study within a multidisciplinary approach. Archaeometry. 2002;44:343-52.

52. Jans MME, Nielsen-Marsh CM, Smith Cl, Collins MJ, Kars H. Characterisation of microbial attack on archaeological bone. J Archaeol Sci. 2004;31:87-95.

53. Trueman CN, Tuross N. Trace elements in recent and fossil bone apatite. Rev Mineral Geochem. 2002;48:489-521.

54. Rasmussen KL, Bjerregaard P, Gommeson PH, Jensen OL. Arsenic in Danish and Swedish mesolithic and neolithic human bones-diet or diagenesis? J Archaeol Sci. 2009;36:2826-34.

55. Byrne KB, Parris DC. Reconstruction of the diet of the Middle Woodland Amerindian population at Abbott Farm by bone trace-element analysis. Am J Phys Anthropol. 1987;74:373-84.

56. López-González F, Anglade A, Vidal-Romaní JR. Deciphering bone depositional sequences in caves through the study of manganese coatings. Archaeol Sci. 2006;33:707-17.

57. Parker RB, Toots H. Minor elements in fossil bone. Geo Soc Am Bull. 1970;81:925-32.

58. Shafer MM, Siker M, Overdier JT, RamsI PC, Teschler-Nicola M, Farrell PM. Enhanced methods of assessment of the trace element composition of Iron Age bone. Sci Total Environ. 2008;401:144-61.

59. Schutkowski H, Herrmann B. Geographical variation of subsistence strategies in early mediaeval populations of southwestern Germany. J Archaeol Sci. 1996:23:823-31.

60. Schutkowski H, Herrmann B, Wiedemann F, Bocherens H, Grupe G Diet, status and decomposition at Weingarten: trace element and isotope analyses on early medieval skeletal material. J Archaeol Sci. 1999:26:675-85

61. Fabig A, Herrmann B. Trace elements in buried human bones: intrapopulation variability of $\mathrm{Sr} / \mathrm{Ca}$ and $\mathrm{Ba} / \mathrm{Ca}$ ratios - diet or diagenesis? Naturwissenschaften. 2002;89:115-9.

62. Castro W, Hoogewerff J, Latkoczy C, Almirall JR. Application of laser ablation (LA-ICP-SF-MS) for the elemental analysis of bone and teeth samples for discrimination purposes. Forensic Sci Int. 2010;195:17-27.

63. Boscher-Barre N, Trocellier P. Nuclear microprobe study of a woman's skeleton from the sixth century. Nucl Instrum Methods Phys Res. 1993:73:413-6.

64. Jankuhn S, Butz T, Flagmeyer RH, Reinert T, Vogt J, Barckhausen B, et al. Ion microprobe analyses of ancient human bone. Nuclear Inst Methods Phys Res B. 1998;136-138:329-33.

65. Nielsen-Marsh CM, Hedges REM. Patterns of diagenesis in bone II: effects of acetic acid treatment and the removal of diagenic $\mathrm{CO}_{3}{ }^{2-}$. J Archaeol Sci. 2000;27:1151-9.

66. Sillen A. Biogenic and diagenic Sr/Ca in Plio-Pleistocene fossils of the Omo Shungura formation. Paleobiology. 1986;12:311-23.

67. Sillen $\mathrm{A}$, Sealy JC, et al. Diagenesis of strontium in fossil bone: a reconsideration of Nelson et al. (1986). J Archaeol Sci. 1995;22:313-20.

68. Koch PL, Halliday AN, Walter LM, Stearley RF, Huston TJ, Smith GR. Sr isotopic composition of hydroxyapatite from recent and fossil salmon: the record of lifetime migration and diagenesis. Earth Planet Sci Lett. 1992:108:277-87.

69. Tuross N, Behrensmeyer AK, Eanes ED. Strontium increases and crystallinity changes in taphonomic and archaeological bone. J Archaeol Sci. 1989;16:661-72.

70. Hedges REM, Millard AR, Pike AWG. Measurements and relationships of diagenetic alteration of bone from three archaeological sites. J Archaeol Sci. 1995:22:201-9.

71. Milner GR, Boldsen JL. Estimating age and sex from the skeleton, a paleopathological perspective. In: Grauer AL, editor. A companion to paleopathology. Chichester: Wiley-Blackwell; 2012. p. 268-84.

72. Milner GR, Ferrell RJ. Conflict and death in a late prehistoric community in the American Midwest. Anthrop Anz. 2011;68:415-36.
73. Feveile C, Søvsø M. Ribe genopstår. In: Christensen SB, editor. Ribe bys historie. Esbjerg: Sydvestjyske Museer and Esbjerg menighedsråd; 2008. p. 38.

74. Rasmussen KL. Arkæometriske undersøgelser af Sct Nicolai Kirke. In: Rasmussen KL, editor. Svendborg Sct Nicolai. Svendborg: Svendborg Museum; 2008. p. 276-315.

75. Kristensen HK. The Franciscan Friary of Svendborg. The archaeology of Svendborg, Denmark, volume 6. Svendborg: Svendborg Museum; 1994.

76. Kohn MJ, Moses RJ. Trace element diffusivities in bone rule out simple diffusive uptake during fossilization but explain in vivo uptake and release. Proc Natl Acad Sci USA. 2013;110:419-42.

77. Man Reference. Reference man: Anatomical, physiological and metabolic characteristics, ICRP (international commission on radiological protection) publication 23. Amsterdam: Elsevier; 1975.

78. Beneš B, Jakubec K, Šmíd J, Spěvačková V. Determination of thirty-two elements in human autopsy tissue. Biol Trace Elem Res. 2000;75:195-203.

79. Brodziak-Dopierałaa B, Kwapuliński J, Sobczyk K, Wiechuła D. The content of manganese and iron in hip joint tissue. J Trace Elem Med Biol. 2013;27:208-12.

80. Jurkiewicz A, Wiechula D, Nowak R, GaźdizikT, Loska K. Metal content in femoral head spongious bone of people living in regions of different degrees of environmental pollution in southern and middle Poland. Ecotoxicol Environ Saf. 2004;59:95-101.

81. Jurkiewicz A, Wiechula D, Nowak R, Loska K. Lead content in the femoral heads of inhabitants of Silesia (Poland). JTrace Elem Med Biol. 2005;19:165-70.

82. Baranowska I, Czernicki K, Aleksandrowicz R. The analysis of lead, cadmium, zinc, copper and nickel content in human bones from the upper Silesian industrial district. Sci Total Environ. 1995:159:155-62.

83. Budis H, Kalisinska E, Lanocha N, Kosik-Bogacka DI, Sokolowski S, Dobieck $\mathrm{K}$, et al. The concentration of manganese, iron, and strontium in hip joint bone obtained from patients undergoing hip replacement surgery. J Trace Elem Med Biol. 2014;28:39-44.

84. Lanocha N, Kalisinska E, Kosik-Bogacka DI, Budis H, Sokolowski S, Bohatyrewicz A. Concentrations of trace elements in bones of the hip joint from patients after hip replacement surgery. J Trace Elem Med Biol. 2012;26:20-5.

85. Zaichick S, Zaichick V, Karandashev VK, Moskvina IR. The effect of age and gender on 59 trace-element contents in human rib bone investigated by inductively coupled plasma mass spectrometry. Biol Trace Elem Res. 2011;143:41-57.

86. Zaichick S, Zaichick $V$. The effect of age and gender on 38 chemical element contents in human iliac crest investigated by instrumental neutron activation analysis. J Trace Elem Med Biol. 2010;24:1-6.

87. García F, Ortega A, Domingo JL, Corbella J. Accumulation of metals in autopsy tissues of subjects living in Tarragona county, Spain. J Environ Sci Health A Tox Hazard Subst Environ Eng. 2001:36:1767-86.

88. Bocio A, Nadal M, García F, Domingo JL. Living in the vicinity of a hazardous waste incinerator: concentrations in autopsy tissues. Biol Trace Elem Res. 2005;106:41-50.

89. Gerhardsson L, Akantis A, Lundström NG, Nordberg GF, Schütz A, Skerfving $\mathrm{S}$. Lead concentrations in cortical and trabecular bones in deceased smelter workers. J Trace Elem Med Biol. 2005:19:209-15.

90. Arnay-de-la-Rosa M, Gonzalez-Reimers E, Velasco-Vazquez J, Galindo-Martin L, Delgado-Ureta E, Santolaria-Fernandez F, et al. Comparison of bone lead in pre-Hispanic, 18th century and modern population of Tenerife. Sci Total Environ. 1998:209:107-11.

91. Zhang Y, Cheng F, Li D, Wang Y, Zhang G, Liao W, et al. Investigation of elemental content distribution in femoral head slice with osteoporosis by SRXRF microprobe. Biol Trace Elem Res. 2005;103:177-85.

92. Yoshinaga J, Suzuki T, Morita M, Hayakawa M. Trace elements in ribs of elderly people and elemental variation in the presence of chronic diseases Sci. Total Environ. 1995;162:239-52.

93. Kuo HW, Kuo SM, Chou CH, Lee TC. Determination of 14 elements in Taiwanese bones. Sci Total Environ. 2000;255:45-54.

94. Rolle-McFarland D, Liu Y, Zhou J, Mostafaei F, Zhou Y, Li Y, et al. Development of a cumulative exposure index (CEl) for manganese and comparison with bone manganese and other biomarkers of manganese exposure. Int J Environ Res Public Health. 2018;15:1341. https://doi. org/10.3390/ijerph15071341. 
95. Aaron JE. Periosteal Sharpey's fibers: a novel bone matrix regulatory system? Front Endocrinol. 2012;3:98. https://doi.org/10.3389/fendo 2012.00098.

96. Al-Qtaitat A, Shore RC, Aaron JE. Structural changes in the ageing periosteum using collagen III immune-staining and chromium labelling as indicators. J Musculoskelet Neuronal Interact. 2010;10:112-23.

97. Hirashima S, Ohta K, Kanazawa T, Uemura K, Togo A, Yoshitomi M, et al. Anchoring structure of the calvarial periosteum revealed by focused ion beam/scanning electron microscope tomography. Sci Rep. 2015;5:17511. https://doi.org/10.1038/spre17511.
98. Milovanovic P, vom Scheidt A, Mletzko K, Sarau G, Püschel K, Djuric M, et al. Bone tissue aging affects mineralization of cement lines. Bone. 2018;110:187-93.

\section{Publisher's Note}

Springer Nature remains neutral with regard to jurisdictional claims in published maps and institutional affiliations.

\section{Submit your manuscript to a SpringerOpen ${ }^{\circ}$ journal and benefit from:}

- Convenient online submission

- Rigorous peer review

- Open access: articles freely available online

- High visibility within the field

- Retaining the copyright to your article

Submit your next manuscript at springeropen.com 